\title{
LEVEL II SCOUR ANALYSIS FOR BRIDGE 10 (WFIETH00170010) on TOWN HIGHWAY 17, crossing TAFT BROOK, WESTFIELD, VERMONT
}

U.S. Geological Survey Open-File Report 97-344

Prepared in cooperation with

VERMONT AGENCY OF TRANSPORTATION and

FEDERAL HIGHWAY ADMINISTRATION 


\section{LEVEL II SCOUR ANALYSIS FOR BRIDGE 10 (WFIETH00170010) on TOWN HIGHWAY 17, crossing TAFT BROOK, WESTFIELD, VERMONT By SCOTT A. OLSON}

U.S. Geological Survey Open-File Report 97-344

Prepared in cooperation with

VERMONT AGENCY OF TRANSPORTATION and

FEDERAL HIGHWAY ADMINISTRATION 


\title{
U.S. DEPARTMENT OF THE INTERIOR BRUCE BABBITT, Secretary
}

\author{
U.S. GEOLOGICAL SURVEY \\ Gordon P. Eaton, Director
}

For additional information write to:

District Chief

U.S. Geological Survey 361 Commerce Way

Pembroke, NH 03275-3718
Copies of this report may be purchased from:

U.S. Geological Survey

Branch of Information Services

Open-File Reports Unit

Box 25286

Denver, CO 80225-0286 


\section{CONTENTS}

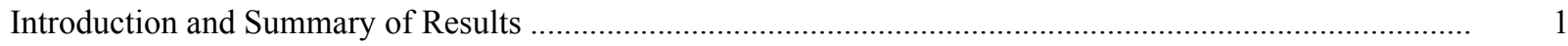

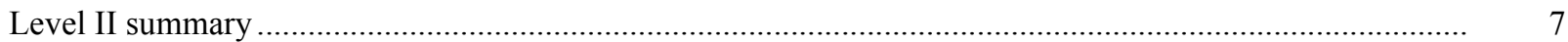

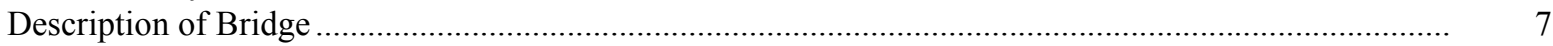



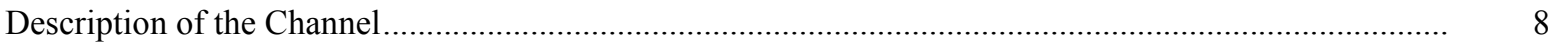

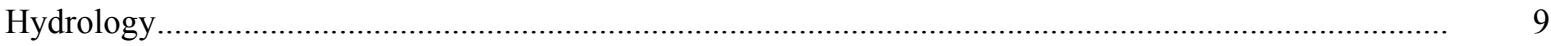

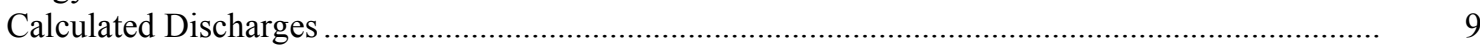

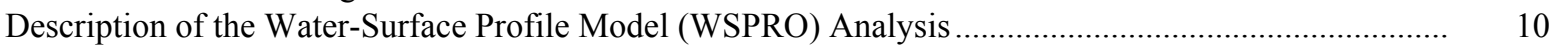

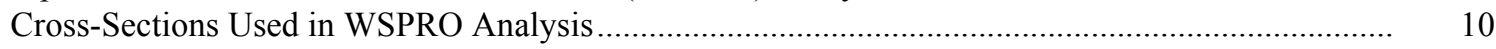

Data and Assumptions Used in WSPRO Model ..................................................................... 11

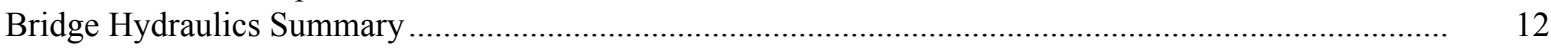

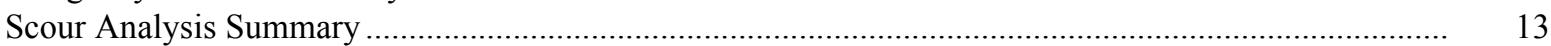

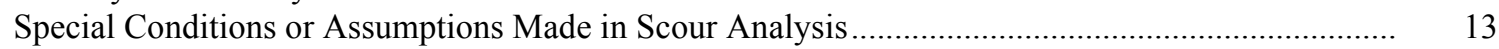

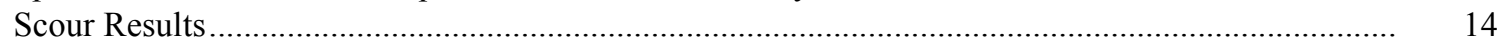

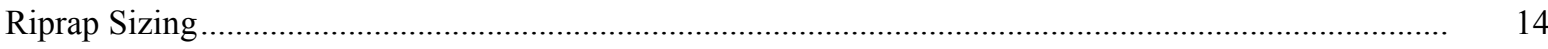

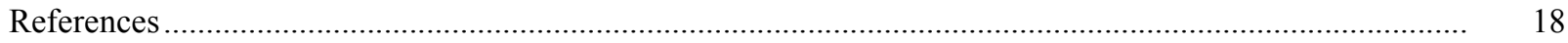

Appendixes:

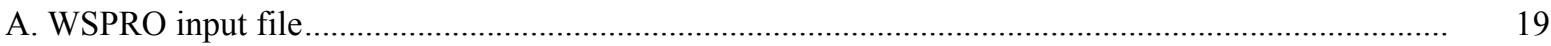

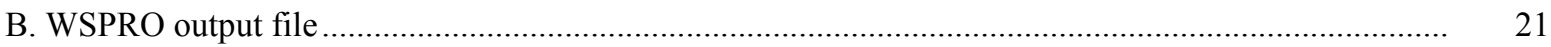

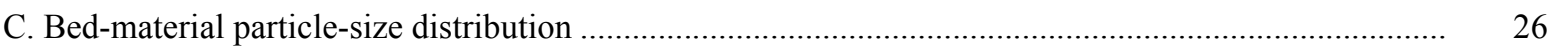

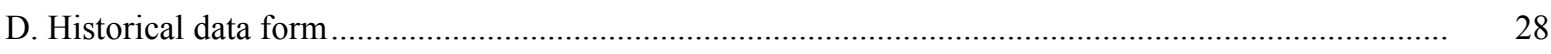

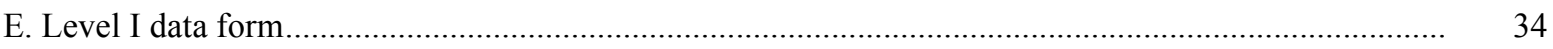

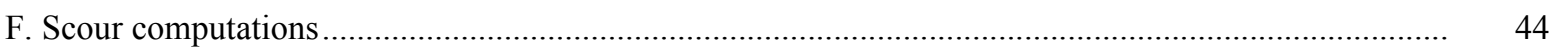

\section{FIGURES}

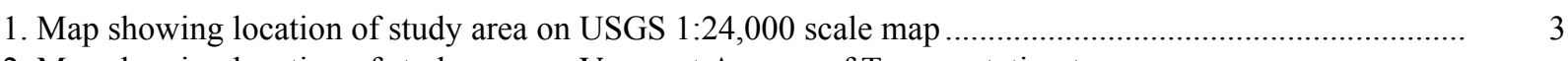

2. Map showing location of study area on Vermont Agency of Transportation town
highway map

3. Structure WFIETH00170010 viewed from upstream (June 26, 1995) .................................................... 5

4. Downstream channel viewed from structure WFIETH00170010 (June 26, 1995). ............................... 5



6. Structure WFIETH00170010 viewed from downstream (June 26, 1995) .......................................... 6

7. Water-surface profiles for the 100- and 500-year discharges at structure

WFIETH00170010 on Town Highway 17, crossing Taft Brook,

Westfield, Vermont.

8. Scour elevations for the 100- and 500-year discharges at structure

WFIETH00170010 on Town Highway 17, crossing Taft Brook,

Westfield, Vermont.

\section{TABLES}

1. Remaining footing/pile depth at abutments for the 100-year discharge at structure

WFIETH00170010 on Town Highway 17, crossing Taft Brook,

Westfield, Vermont.

2. Remaining footing/pile depth at abutments for the 500-year discharge at structure

WFIETH00170010 on Town Highway 17, crossing Taft Brook,

Westfield, Vermont.

5

5

6

6




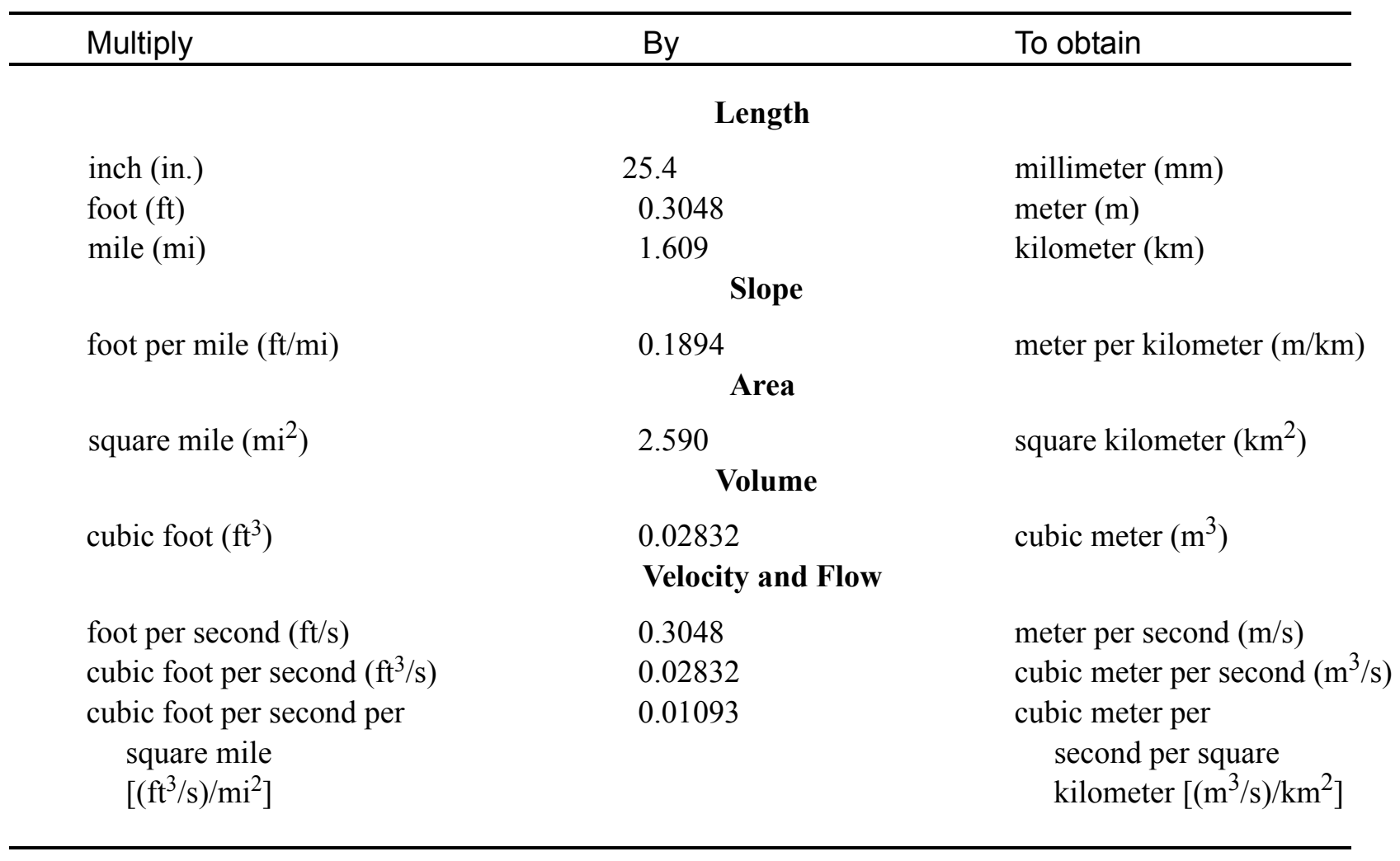

\section{OTHER ABBREVIATIONS}

$\begin{array}{lrlr}\mathrm{BF} & \text { bank full } & \text { LWW } & \text { left wingwall } \\ \mathrm{cfs} & \text { cubic feet per second } & \text { MC } & \text { main channel } \\ \mathrm{D}_{50} & \text { median diameter of bed material } & \text { RAB } & \text { right abutment } \\ \mathrm{DS} & \text { downstream } & \text { RABUT } & \text { face of right abutment } \\ \mathrm{elev} & \text { elevation } & \text { RB } & \text { right bank } \\ \mathrm{f} / \mathrm{p} & \text { flood plain } & \text { ROB } & \text { right overbank } \\ \mathrm{ft}^{2} & \text { square feet } & \text { RWW } & \text { right wingwall } \\ \mathrm{ft} / \mathrm{ft} & \text { feet per foot } & \text { TH } & \text { town highway } \\ \mathrm{JCT} & \text { junction } & \text { UB } & \text { under bridge } \\ \mathrm{LAB} & \text { left abutment } & \text { US } & \text { upstream } \\ \mathrm{LABUT} & \text { face of left abutment } & \text { USGS } & \text { United States Geological Survey } \\ \mathrm{LB} & \text { left bank } & \text { VTAOT Vermont Agency of Transportation } \\ \mathrm{LOB} & \text { left overbank } & \text { WSPRO } & \text { water-surface profile model }\end{array}$

In this report, the words "right" and "left" refer to directions that would be reported by an observer facing downstream. Sea level: In this report, "sea level" refers to the National Geodetic Vertical Datum of 1929-- a geodetic datum derived from a general adjustment of the first-order level nets of the United States and Canada, formerly called Sea Level Datum of 1929.

In the appendices, the above abbreviations may be combined. For example, USLB would represent upstream left bank. 


\title{
LEVEL II SCOUR ANALYSIS FOR BRIDGE 10 (WFIETH00170010) ON TOWN HIGHWAY 17, CROSSING TAFT BROOK, WESTFIELD, VERMONT
}

\author{
By Scott A. Olson
}

\section{INTRODUCTION AND SUMMARY OF RESULTS}

This report provides the results of a detailed Level II analysis of scour potential at structure WFIETH00170010 on Town Highway 17 crossing Taft Brook, Westfield, Vermont (figures $1-8)$. A Level II study is a basic engineering analysis of the site, including a quantitative analysis of stream stability and scour (U.S. Department of Transportation, 1993). Results of a Level I scour investigation also are included in Appendix E of this report. A Level I investigation provides a qualitative geomorphic characterization of the study site. Information on the bridge, gleaned from Vermont Agency of Transportation (VTAOT) files, was compiled prior to conducting Level I and Level II analyses and is found in Appendix D.

The site is in the Green Mountain section of the New England physiographic province in northern Vermont. The 2.39- $\mathrm{mi}^{2}$ drainage area is in a predominantly rural and forested basin. In the vicinity of the study site, the immediate channel banks have thick woody vegetation while the overbanks are grass or pasture.

In the study area, Taft Brook has an incised, sinuous channel with a slope of approximately $0.04 \mathrm{ft} / \mathrm{ft}$, an average channel top width of $38 \mathrm{ft}$ and an average bank height of $6 \mathrm{ft}$. The predominant channel bed material is cobble with a median grain size $\left(D_{50}\right)$ of $85.3 \mathrm{~mm}$ $(0.280 \mathrm{ft})$. The geomorphic assessment at the time of the Level I and Level II site visit on June 26, 1995, indicated that the reach was stable.

The Town Highway 17 crossing of Taft Brook is a 26-ft-long, two-lane bridge consisting of one 24-foot concrete span (Vermont Agency of Transportation, written communication, March 7, 1995). The opening length of the structure parallel to the bridge face is $23.1 \mathrm{ft}$.The bridge is supported by vertical, concrete abutments with wingwalls. The channel is skewed approximately 15 degrees to the opening while the opening-skew-to-roadway is 25 degrees.

There is $0.1 \mathrm{ft}$ (vertical) undermining of both abutments and 0.8 feet of undermining at the downstream right wingwall. Scour countermeasures at the site include sparsely placed type2 stone fill (less than 36 inches diameter) at the ends of each wingwall. Additional details describing conditions at the site are included in the Level II Summary and Appendices D and $\mathrm{E}$. 
Scour depths and recommended rock rip-rap sizes were computed using the general guidelines described in Hydraulic Engineering Circular 18 (Richardson and others, 1995). Total scour at a highway crossing is comprised of three components: 1) long-term streambed degradation; 2) contraction scour (due to accelerated flow caused by a reduction in flow area at a bridge) and; 3 ) local scour (caused by accelerated flow around piers and abutments). Total scour is the sum of the three components. Equations are available to compute depths for contraction and local scour and a summary of the results of these computations follows.

Contraction scour for all modelled flows ranged from 0.1 to $0.4 \mathrm{ft}$. The worst-case contraction scour occurred at the 500-year discharge. Abutment scour at the left abutment ranged from 6.1 to $7.7 \mathrm{ft}$. Abutment scour at the right abutment ranged from 4.3 to 5.4 $\mathrm{ft}$.The worst-case abutment scour occurred at the 500-year discharge for both abutments. Additional information on scour depths and depths to armoring are included in the section titled "Scour Results". Scoured-streambed elevations, based on the calculated scour depths, are presented in tables 1 and 2. A cross-section of the scour computed at the bridge is presented in figure 8 . Scour depths were calculated assuming an infinite depth of erosive material and a homogeneous particle-size distribution.

It is generally accepted that the Froehlich equation (abutment scour) gives "excessively conservative estimates of scour depths" (Richardson and others, 1995, p. 47). Usually, computed scour depths are evaluated in combination with other information including (but not limited to) historical performance during flood events, the geomorphic stability assessment, existing scour protection measures, and the results of the hydraulic analyses. Therefore, scour depths adopted by VTAOT may differ from the computed values documented herein. 


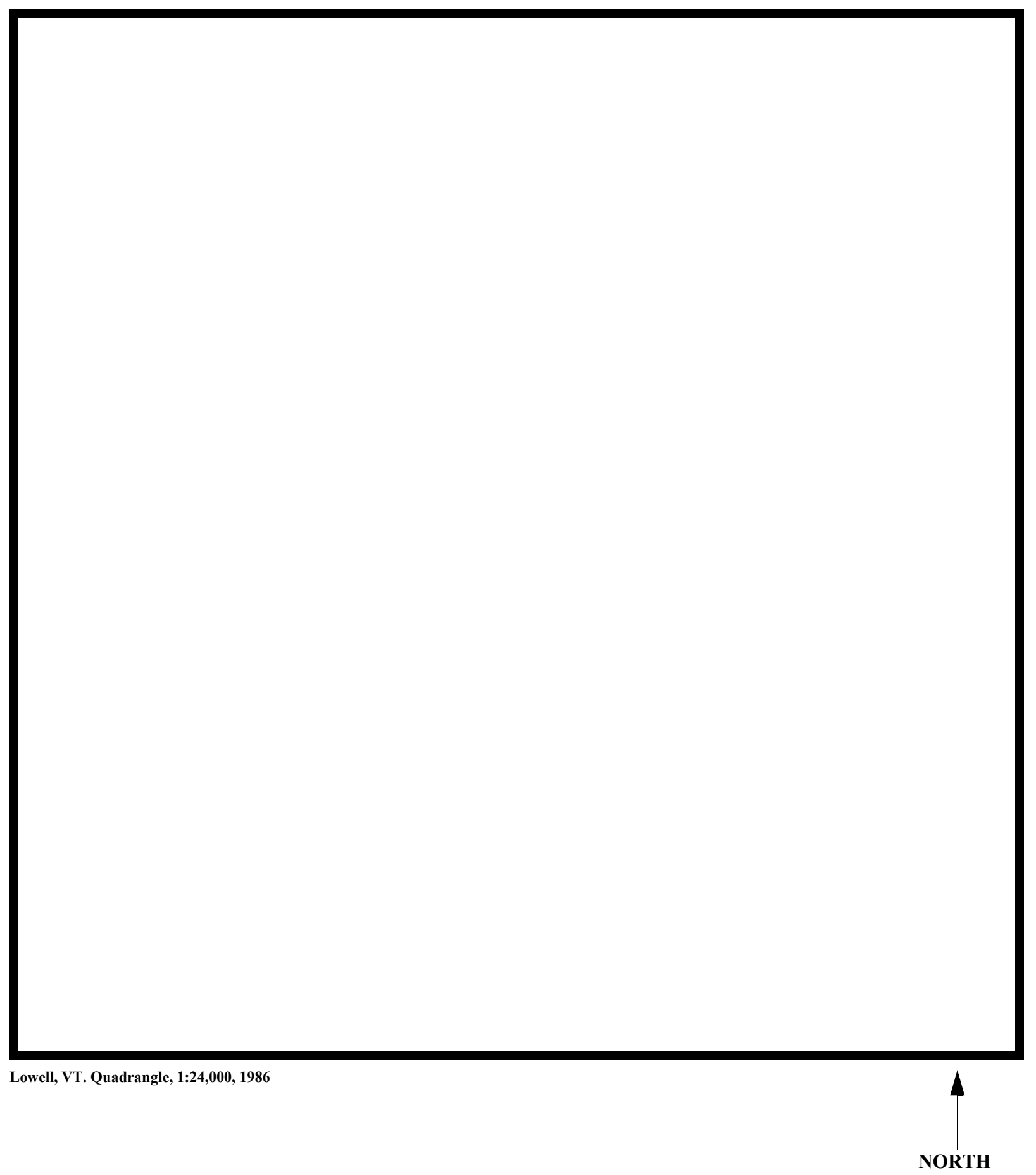

Figure 1. Location of study area on USGS 1:24,000 scale map. 
Figure 2. Location of study area on Vermont Agency of Transportation town highway map. 

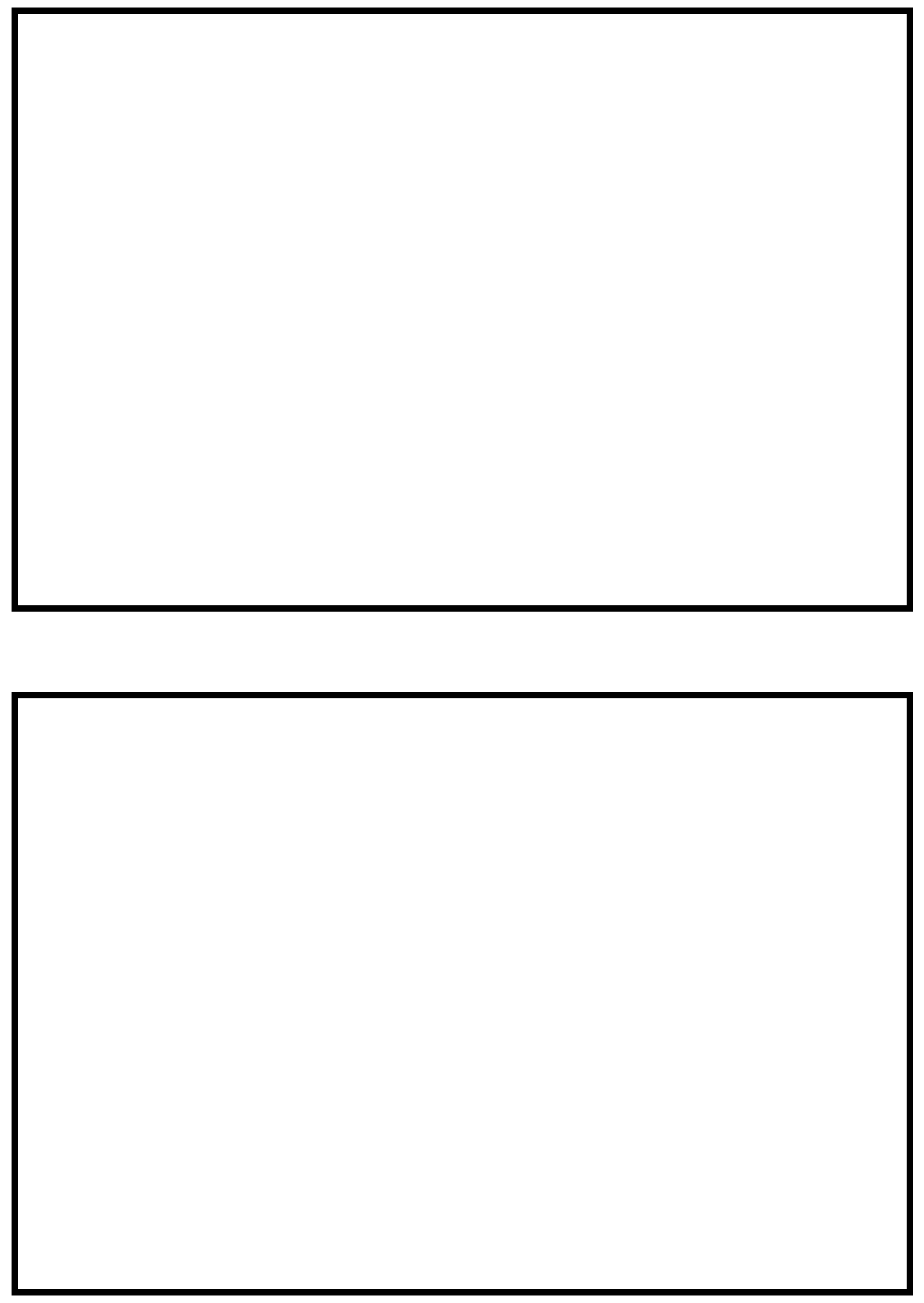

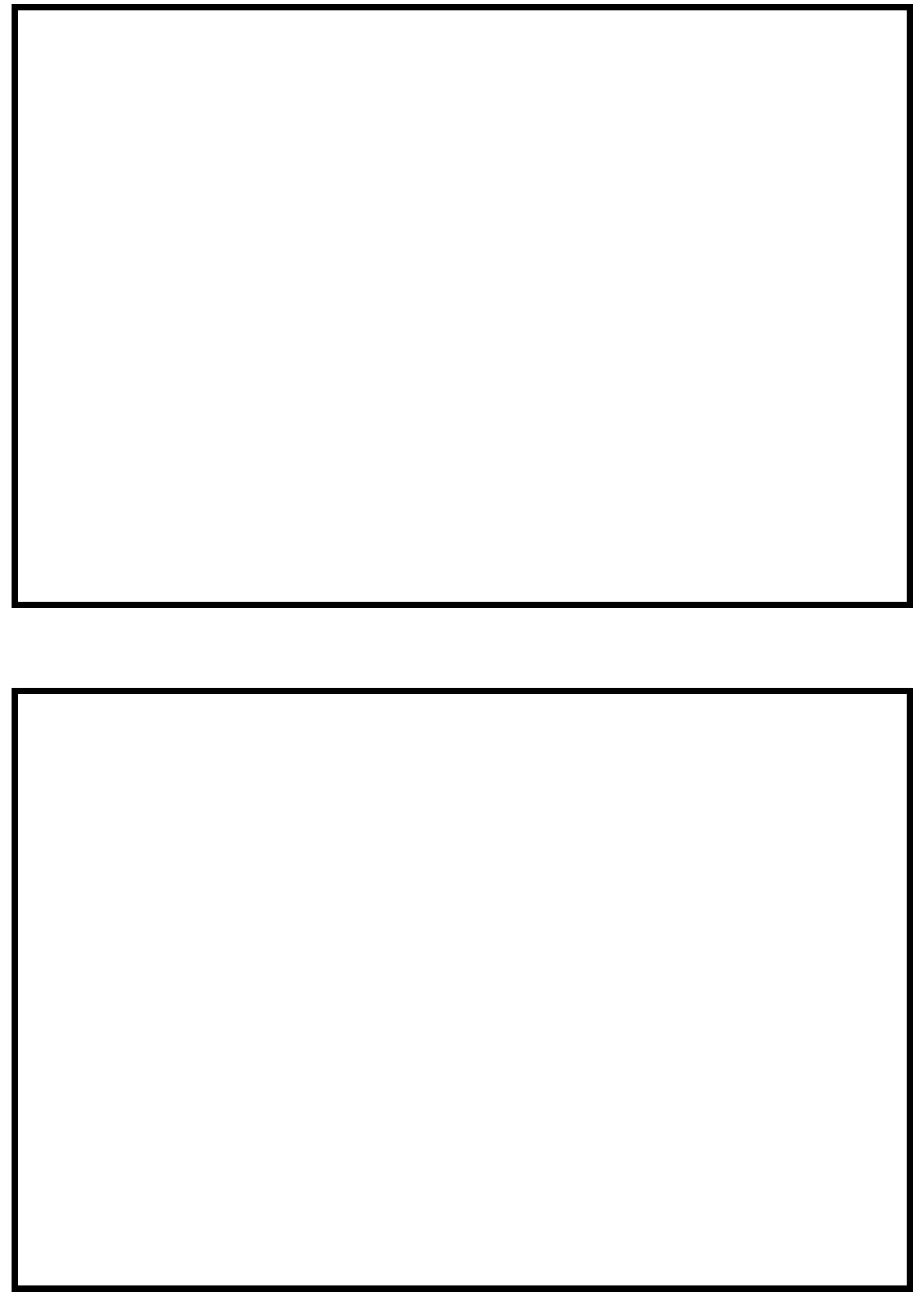


\section{LEVEL II SUMMARY}

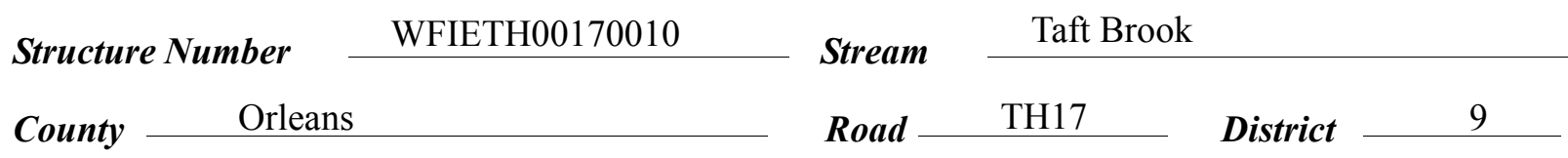

\section{Description of Bridge}



Abutments and wingwalls are concrete. Both abutments are undermined up to $0.1 \mathrm{ft}$. The downstream right wingwall is undermined as much as $0.8 \mathrm{ft}$.

$$
\text { Y }
$$$$
15
$$

Is bridge skewed to flood flow according to 'survey?

Angle

$6 / 26 / 95$

Debris accumulation on bridge at time of Level I or Level II site visit:

$$
\begin{gathered}
\text { Date af insnortion } \\
0
\end{gathered} \quad \begin{gathered}
\text { Percent of rhanual } \\
\text { blocked inortzontatly }
\end{gathered}
$$

\section{Percent of rhamnal blocked nortzontatly}$$
95
$$

Level I

Level II entire channel about 80 feet upstream.

Potential for debris
0
Percent of $6 / 26 /$ inel
blocked verticatty 0

June 26, 1995. The upstream debris could get caught at bridge in a future event. Doseriho anv fonturos noar ar at tho hridos that mav, affort flow (includo ahsorvation dato) 


\section{Description of the Geomorphic Setting}

General topography The channel is located within moderate relief, non-alluvial valley with no flood plains. Left of the bridge is a $350 \mathrm{ft}$ wide, flat, terrace-like feature.

Geomorphic conditions at bridge site: downstream (DS), upstream (US)

Date of inspection $\quad 6 / 26 / 95$

DS left: $\quad$ Steep channel bank to a wide terrace-like feature.

DS right: $\quad$ Steep channel bank to moderately sloped overbank.

US left: $\quad$ Steep channel bank to a wide terrace-like feature.

US right: Steep channel bank to moderately sloped overbank.

\section{Description of the Channel}

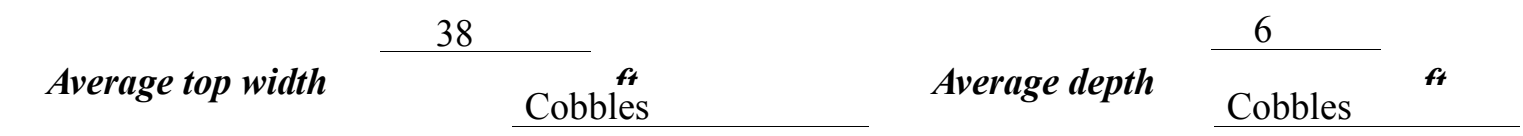

Predominant bed material

Bank material

Straight and stable

with non-alluvial channel boundaries.

$6 / 26 / 95$

Vegetative co 1 Trees and brush with field grasses on the overbank.

DS left: $\quad$ Trees and brush with lawn and trees on the overbank.

DS right: $\quad$ Trees and brush with lawn on the overbank.

US left: $\quad$ Trees and brush with lawn and trees on the overbank.

US right: $\quad \underline{\mathrm{Y}}$

Do banks appear stable? -

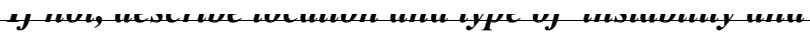

date of observatton.

The assessment of

$6 / 26 / 95$ noted debris blocking the entire channel about 80 feet upstream of the bridge. Describe any obstructions in channel and date of observation. 


\title{
Hydrology
}

Drainage area $\quad 2.39 \boldsymbol{m i}^{2}$

Percentage of drainage area in physiographic provinces: (approximate)

Physiographic province/section

New England/Green Mountain
Percent of drainage area 100

\begin{abstract}
Is drainage area considered rural or urban?
Rural None.

urbanization:

Describe any significant
\end{abstract}

Is there a USGS gage on the stream of interest?

No

USGS gage description

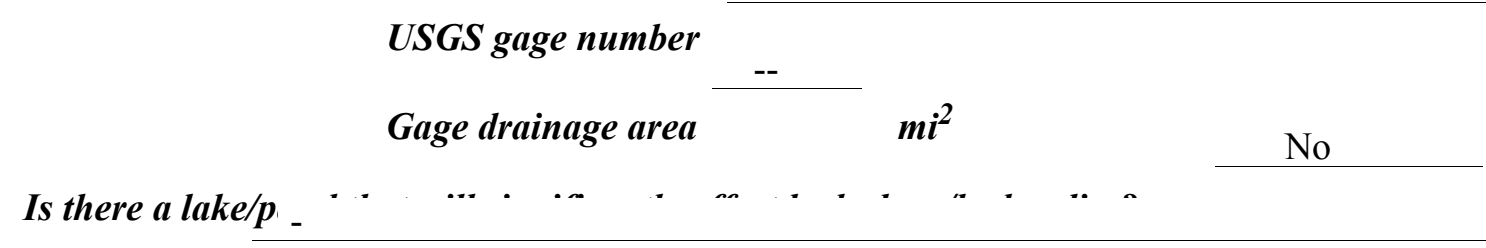

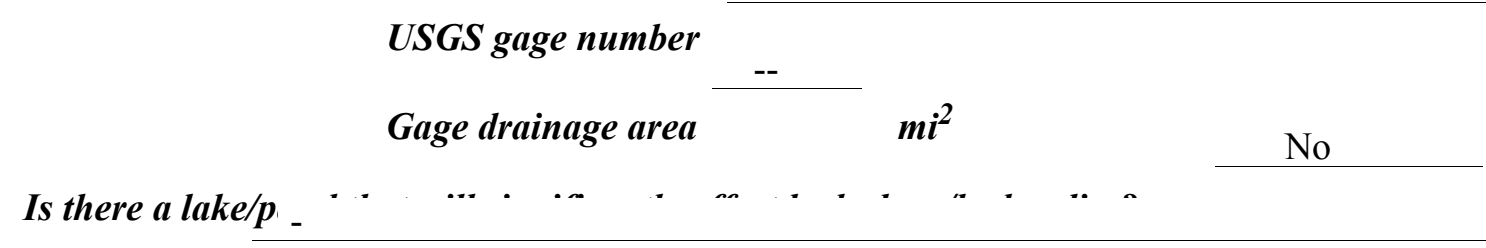

Is there a lake/p.

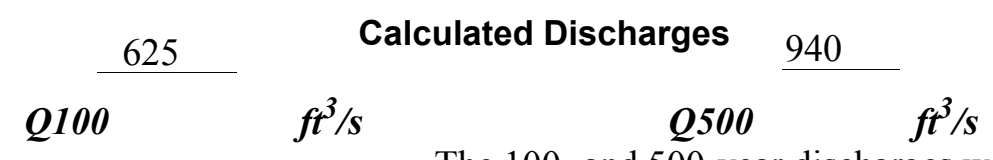

The 100- and 500-year discharges were computed

using methods described in "Peak rates of runoff in the New England Hill and Lowland area" (Potter, $1957 \mathrm{~b}$ ) and graphically extrapolated to the 500-year discharge. These results were chosen due to their central tendency among other empirical techniques (Benson, 1962; Johnson and Tasker, 1974; FHWA, 1983; Talbot, 1887). For example, the Q100 result was the median and within 3 per cent of the average. 


\section{Description of the Water-Surface Profile Model (WSPRO) Analysis}

Datum for WSPRO analysis (USGS survey, sea level, VTAOT plans)

USGS survey

Datum tie between USGS survey and VTAOT plans

None

Description of reference marks used to determine USGS datum. $\quad$ RM1 is a chiseled X on

top of the downstream end of the right abutment (elev. $499.49 \mathrm{ft}$, arbitrary survey datum). RM2

is a chiseled X on top of the upstream end of the left abutment (elev. $499.46 \mathrm{ft}$, arbitrary survey

datum).

\section{Cross-Sections Used in WSPRO Analysis}

\begin{tabular}{|c|c|c|c|}
\hline${ }^{1}$ Cross-section & $\begin{array}{c}\text { Section } \\
\text { Reference } \\
\text { Distance } \\
\text { (SRD) in feet }\end{array}$ & $\begin{array}{c}{ }^{2} \text { Cross-section } \\
\text { development }\end{array}$ & Comments \\
\hline EXITX & -36 & 1 & Exit section \\
\hline FULLV & 0 & 2 & $\begin{array}{l}\text { Downstream Full-valley } \\
\text { section (Templated from } \\
\text { EXITX) }\end{array}$ \\
\hline BRIDG & 0 & 1 & Bridge section \\
\hline RDWAY & 14 & 1 & Road Grade section \\
\hline APPRO & 53 & 1 & Approach section \\
\hline
\end{tabular}

${ }^{1}$ For location of cross-sections see plan-view sketch included with Level I field form, Appendix E. For more detail on how cross-sections were developed see WSPRO input file. 


\section{Data and Assumptions Used in WSPRO Model}

Hydraulic analyses of the reach were done by use of the Federal Highway Administration's WSPRO step-backwater computer program (Shearman and others, 1986, and Shearman, 1990). The analyses reported herein reflect conditions existing at the site at the time of the study. Furthermore, in the development of the model it was necessary to assume no accumulation of debris or ice at the site. Results of the hydraulic model are presented in the Bridge Hydraulic Summary, Appendix B, and figure 7.

Channel roughness factors (Manning's " $n$ ") used in the hydraulic model were estimated using field inspections at each cross section following the general guidelines described by Arcement and Schneider (1989). Final adjustments to the values were made during the modelling of the reach. Channel " $n$ " values for the reach ranged from 0.045 to 0.065 , and overbank " $\mathrm{n}$ " values ranged from 0.045 to 0.075 .

Normal depth at the exit section (EXITX) was assumed as the starting water surface. This depth was computed by use of the slope-conveyance method outlined in the user's manual for WSPRO (Shearman, 1990). The slope used was $0.0365 \mathrm{ft} / \mathrm{ft}$ which was determined from surveyed thalweg points downstream of the bridge. For the 500 -year discharge, $940 \mathrm{cfs}$, this slope resulted in a normal depth that was supercritical. However, the computed normal depth was only $0.14 \mathrm{ft}$ below critical depth and thus, the use of the critical water surface to start the 500-year model was considered appropriate.

The approach section (APPRO) was surveyed one bridge length upstream of the upstream face as recommended by Shearman and others (1986). This location also provides a consistent method for determining scour variables.

For the 100- and 500-year discharges, WSPRO assumes critical depth at the bridge section. Supercritical models were developed for these discharges. After analyzing both the supercritical and subcritical profiles for each discharge, it can be determined that the water

surface profile does pass through critical depth within the bridge opening. Thus, the assumptions of critical depth at the bridge are satisfactory solutions. 


\section{Bridge Hydraulics Summary}

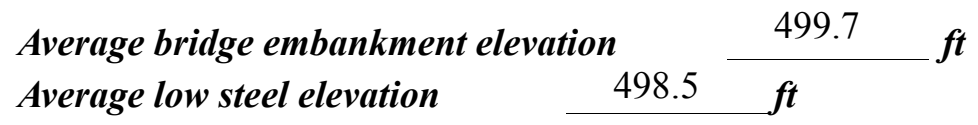

$$
\text { 100-year discharge } \quad 625 \quad \mathrm{ft}^{3} / \mathrm{s}
$$

Water-surface elevation in bridge opening $\quad 494.2 \quad f t$

Road overtopping? ___ N Discharge over road _ _

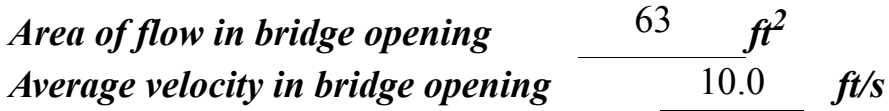

$\begin{array}{llll}\text { Maximum WSPRO tube velocity at bridge } & 11.9 \mathrm{ft} / \mathrm{s}\end{array}$

Water-surface elevation at Approach section with bridge 496.6

Water-surface elevation at Approach section without bridge $\quad 495.3$

Amount of backwater caused by bridge

1.3 it

500-year discharge $\quad 940 \quad \mathrm{ft}^{3} / \mathrm{s}$

Water-surface elevation in bridge opening

$495.2 \mathrm{ft}$

Road overtopping? ___ N Discharge over road $-,-1 / s$

Area of flow in bridge opening

Average velocity in bridge opening 83 $f t^{2}$

Maximum WSPRO tube velocity at bridge $11.3 \mathrm{ft} / \mathrm{s}$

13.8 's

Water-surface elevation at Approach section with bridge

Water-surface elevation at Approach section without bridge

Amount of backwater caused by bridge

$1.9, \boldsymbol{t}$

497.9

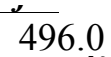

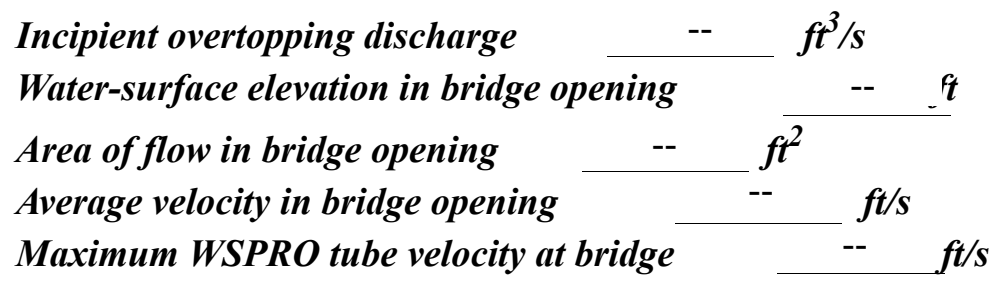

Water-surface elevation at Approach section with bridge

Water-surface elevation at Approach section without bridge

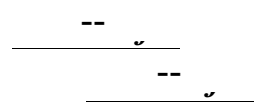
Amount of backwater caused by bridge _ 


\section{Scour Analysis Summary}

\section{Special Conditions or Assumptions Made in Scour Analysis}

Scour depths were computed using the general guidelines described in Hydraulic Engineering Circular 18 (Richardson and others, 1995). Scour depths were calculated assuming an infinite depth of erosive material and a homogeneous particle-size distribution. The results of the scour analysis are presented in tables 1 and 2 and a graph of the scour depths is presented in figure 8.

Contraction scour was computed by use of the clear-water contraction scour equation (Richardson and others, 1995, p. 32, equation 20). Results of this analysis are presented in figure 8 and tables 1 and 2. For the 100-year event, the streambed armoring depths computed suggest that armoring will not limit the depth contraction scour. For the 500-year discharge, less than five percent of the bed material was larger than the critical grain size (incipient motion size), thus, armoring is not probable for this event.

Abutment scour was computed by use of the Froehlich equation (Richardson and others, 1995, p. 48, equation 28). Variables for the Froehlich equation include the Froude number of the flow approaching the embankments, the length of the embankment blocking flow, and the depth of flow approaching the embankment less any roadway overtopping. 


\section{Scour Results}

\section{0-yr discharge 500-yr discharge}

Contraction scour:

(Scour depths in feet)

Main channel

Live-bed scour

Clear-water scour

Depth to armoring

Left overbank

Right overbank

Local scour:

Abutment scour

Left abutment

6.1

7.7

$4.3-$

$5.4-$

Right abutment

Pier scour

Pier 1

Pier 2

Pier 3

\section{Abutments:}

Left abutment

Right abutment

Piers:

Pier 1

Pier 2

Incipient overtopping discharge 


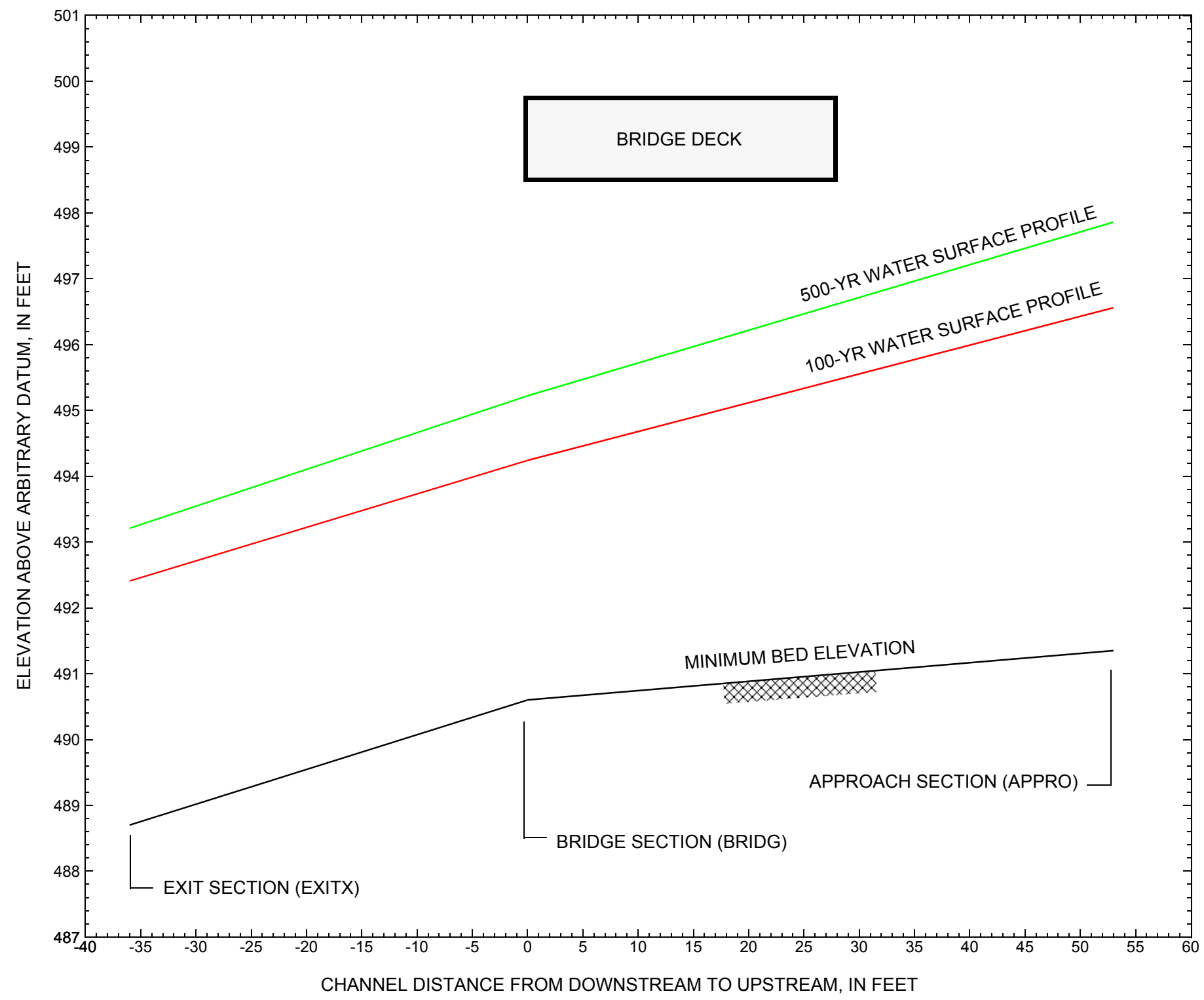

Figure 7. Water-surface profiles for the 100- and 500-yr discharges at structure WFIETH00170010 on Town Highway 17, crossing Taft Brook, Westfield, Vermont. 


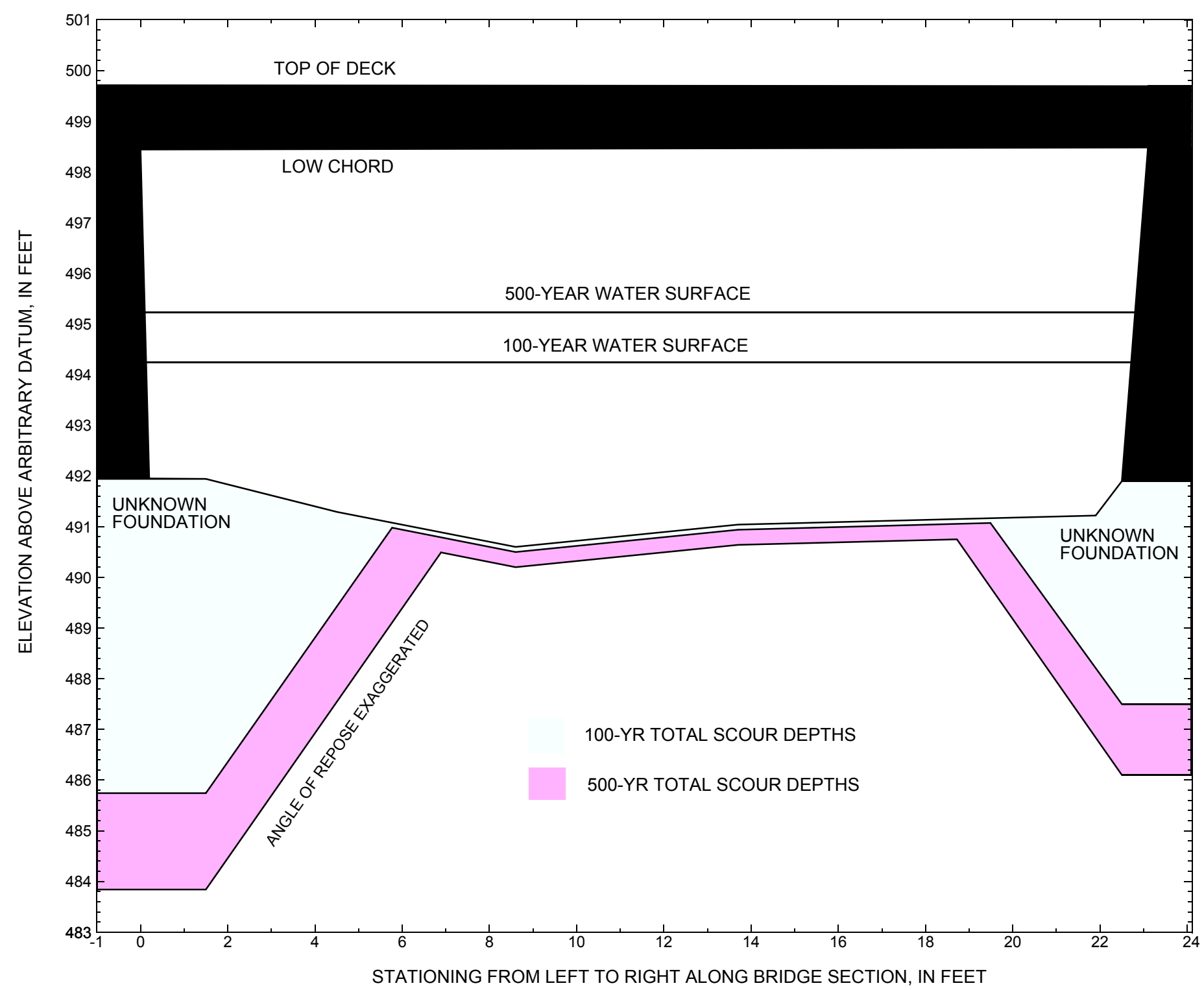

Figure 8. Scour elevations for the 100-yr and 500-yr discharges at structure WFIETH00170010 on Town Highway 17, crossing Taft Brook, Westfield, Vermont. 
Table 1. Remaining footing/pile depth at abutments for the 100-year discharge at structure WFIETH00170010 on Town Highway 17, crossing Taft Brook, Westfield, Vermont. [VTAOT, Vermont Agency of Transportation; --,no data]

\begin{tabular}{|c|c|c|c|c|c|c|c|c|c|c|c|}
\hline Description & Station $^{1}$ & $\begin{array}{l}\text { VTAOT } \\
\text { minimum } \\
\text { low-chord } \\
\text { elevation } \\
\text { (feet) }\end{array}$ & $\begin{array}{l}\text { Surveyed } \\
\text { minimum } \\
\text { low-chord } \\
\text { elevation } \\
\text { (feet) }\end{array}$ & $\begin{array}{c}\text { Bottom of } \\
\text { footing } \\
\text { elevation } \\
\text { (feet) }\end{array}$ & $\begin{array}{l}\text { Channel } \\
\text { elevation at } \\
\text { abutment/ } \\
\text { pier }^{2} \\
\text { (feet) }\end{array}$ & $\begin{array}{l}\text { Contraction } \\
\text { scour depth } \\
\text { (feet) }\end{array}$ & $\begin{array}{l}\text { Abutment } \\
\text { scour } \\
\text { depth } \\
\text { (feet) }\end{array}$ & $\begin{array}{l}\text { Pier } \\
\text { scour } \\
\text { depth } \\
\text { (feet) }\end{array}$ & $\begin{array}{l}\text { Depth of } \\
\text { total scour } \\
\text { (feet) }\end{array}$ & $\begin{array}{c}\text { Elevation of } \\
\text { scour }^{2} \\
\text { (feet) }\end{array}$ & $\begin{array}{c}\text { Remaining } \\
\text { footing/pile } \\
\text { depth } \\
\text { (feet) }\end{array}$ \\
\hline \multicolumn{12}{|c|}{100 -yr. discharge is 625 cubic-feet per second } \\
\hline Left abutment & 0.0 & -- & 498.4 & -- & 491.9 & 0.1 & 6.1 & -- & 6.2 & 485.7 & -- \\
\hline Right abutment & 23.1 & -- & 498.5 & -- & 491.9 & 0.1 & 4.3 & -- & 4.4 & 487.5 & -- \\
\hline
\end{tabular}

1.Measured along the face of the most constricting side of the bridge.

2.Arbitrary datum for this study.

Table 2. Remaining footing/pile depth at abutments for the 500-year discharge at structure WFIETH00170010 on Town Highway 17, crossing Taft Brook, Westfield, Vermont. [VTAOT, Vermont Agency of Transportation; --, no data]

\begin{tabular}{|c|c|c|c|c|c|c|c|c|c|c|c|}
\hline Description & Station $^{1}$ & $\begin{array}{l}\text { VTAOT } \\
\text { minimum } \\
\text { low-chord } \\
\text { elevation } \\
\text { (feet) }\end{array}$ & $\begin{array}{l}\text { Surveyed } \\
\text { minimum } \\
\text { low-chord } \\
\text { elevation } \\
\text { (feet) }\end{array}$ & $\begin{array}{c}\text { Bottom of } \\
\text { footing } \\
\text { elevation } \\
\text { (feet) }\end{array}$ & $\begin{array}{c}\text { Channel } \\
\text { elevation at } \\
\text { abutment/ } \\
\text { pier }^{2} \\
\text { (feet) }\end{array}$ & $\begin{array}{l}\text { Contraction } \\
\text { scour depth } \\
\text { (feet) }\end{array}$ & $\begin{array}{l}\text { Abutment } \\
\text { scour } \\
\text { depth } \\
\text { (feet) }\end{array}$ & $\begin{array}{l}\text { Pier } \\
\text { scour } \\
\text { depth } \\
\text { (feet) }\end{array}$ & $\begin{array}{l}\text { Depth of } \\
\text { total scour } \\
\text { (feet) }\end{array}$ & $\begin{array}{c}\text { Elevation of } \\
\text { scour }^{2} \\
\text { (feet) }\end{array}$ & $\begin{array}{c}\text { Remaining } \\
\text { footing/pile } \\
\text { depth } \\
\text { (feet) }\end{array}$ \\
\hline \multicolumn{12}{|c|}{500 -yr. discharge is 940 cubic-feet per second } \\
\hline Left abutment & 0.0 & -- & 498.4 & -- & 491.9 & 0.4 & 7.7 & -- & 8.1 & 483.8 & -- \\
\hline Right abutment & 23.1 & -- & 498.5 & -- & 491.9 & 0.4 & 5.4 & -- & 5.8 & 486.1 & -- \\
\hline
\end{tabular}

1.Measured along the face of the most constricting side of the bridge.

2.Arbitrary datum for this study. 


\section{SELECTED REFERENCES}

Arcement, G.J., Jr., and Schneider, V.R., 1989, Guide for selecting Manning's roughness coefficients for natural channels and flood plains: U.S. Geological Survey Water-Supply Paper 2339, 38 p.

Barnes, H.H., Jr., 1967, Roughness characteristics of natural channels: U.S. Geological Survey Water-Supply Paper 1849, 213 p.

Benson, M. A., 1962, Factors Influencing the Occurrence of Floods in a Humid Region of Diverse Terrain: U.S. Geological Survey WaterSupply Paper 1580-B, 64 p.

Brown, S.A. and Clyde, E.S., 1989, Design of riprap revetment: Federal Highway Administration Hydraulic Engineering Circular No. 11, Publication FHWA-IP-89-016, 156 p.

Federal Highway Administration, 1983, Runoff estimates for small watersheds and development of sound design: Federal Highway Administration Report FHWA-RD-77-158.

Federal Highway Administration, 1993, Stream Stability and Scour at Highway Bridges: Participant Workbook: Federal Highway Administration Report FHWA-HI-91-011.

Froehlich, D.C., 1989, Local scour at bridge abutments in Ports, M.A., ed., Hydraulic Engineering--Proceedings of the 1989 National Conference on Hydraulic Engineering: New York, American Society of Civil Engineers, p. 13-18.

Hayes, D.C.,1993, Site selection and collection of bridge-scour data in Delaware, Maryland, and Virginia: U.S. Geological Survey WaterResources Investigation Report 93-4017, 23 p.

Interagency Advisory Committee on Water Data, 1982, Guidelines for determining flood flow frequency: U.S. Geological Survey, Bulletin 17B of the Hydrology Subcommittee, $190 \mathrm{p}$.

Johnson, C.G. and Tasker, G.D.,1974, Progress report on flood magnitude and frequency of Vermont streams: U.S. Geological Survey Open-File Report 74-130, 37 p.

Lagasse, P.F., Schall, J.D., Johnson, F., Richardson, E.V., Chang, F., 1995, Stream Stability at Highway Structures: Federal Highway Administration Hydraulic Engineering Circular No. 20, Publication FHWA-IP-90-014, 144 p.

Laursen, E.M., 1960, Scour at bridge crossings: Journal of the Hydraulics Division, American Society of Civil Engineers, v. 86, no. HY2, p. 39-53.

Potter, W. D., 1957a, Peak rates of runoff in the Adirondack, White Mountains, and Maine woods area, Bureau of Public Roads

Potter, W. D., 1957b, Peak rates of runoff in the New England Hill and Lowland area, Bureau of Public Roads

Richardson, E.V. and Davis, S.R., 1995, Evaluating scour at bridges: Federal Highway Administration Hydraulic Engineering Circular No. 18, Publication FHWA-IP-90-017, 204 p.

Richardson, E.V., Simons, D.B., and Julien, P.Y., 1990, Highways in the river environment: Federal Highway Administration Publication FHWA-HI-90-016.

Ritter, D.F., 1984, Process Geomorphology: W.C. Brown Co., Debuque, Iowa, 603 p.

Shearman, J.O., 1990, User's manual for WSPRO--a computer model for water surface profile computations: Federal Highway Administration Publication FHWA-IP-89-027, 187 p.

Shearman, J.O., Kirby, W.H., Schneider, V.R., and Flippo, H.N., 1986, Bridge waterways analysis model; research report: Federal Highway Administration Publication FHWA-RD-86-108, 112 p.

Talbot, A.N., 1887, The determination of water-way for bridges and culverts.

U.S. Department of Transportation, 1993, Stream stability and scour at highway bridges, Participant Workbook: Federal Highway Administration Publication FHWA HI-91-011.

U.S. Geological Survey, 1986, Lowell, Vermont 7.5 Minute Series quadrangle map: U.S. Geological Survey Topographic Maps, Scale $1: 24,000$. 


\section{APPENDIX A: \\ WSPRO INPUT FILE}




\section{WSPRO INPUT FILE}

GR

GR

GR

$\mathrm{N}$

SA

* $\mathrm{XS}$

\section{*}

BR

GR

GR

GR

$\mathrm{N}$

CD

*

XR

GR

GR

*

AS

GR

GR

GR

$\mathrm{N}$

SA

*

HP 1 BRIDG

HP 2 BRIDG

HP 1 APPRO

HP 2 APPRO

*

HP 1 BRIDG

HP 2 BRIDG

HP 1 APPRO

HP 2 APPRO

*

EX

ER

\section{RDWAY}

BRIDG

U.S. Geological Survey WSPRO Input File wfie010.wsp Hydraulic analysis for structure wfieth00170010 Date: 09-APR-97 Westfield bridge 10 over Taft Brook SAO

$\begin{array}{lllllllllllllllllllll}6 & 29 & 30 & 552 & 553 & 551 & 5 & 16 & 17 & 13 & 3 & * & 15 & 14 & 23 & 21 & 11 & 12 & 4 & 7 & 3\end{array}$

$$
\begin{aligned}
& 625 \quad 940 \\
& 0.0365 \quad 0.0365
\end{aligned}
$$

EXITX -36

$$
\begin{aligned}
& -111.2,497.78 \quad-82.8,497.03 \\
& -17.4,493.58 \quad-9.2,495.75 \\
& 13.4,488.70 \quad 22.1,489.41 \\
& 65.1,495.93 \quad 91.0,498.17 \\
& 0.075 \\
& 0.065 \\
& 0.070 \\
& -9.2 \\
& 29.5
\end{aligned}
$$

$-29.4,492.79$

$5.4,489.29$

0.0

$51.5,492.59$

0.030

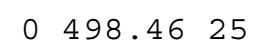

$$
-8.7
$$

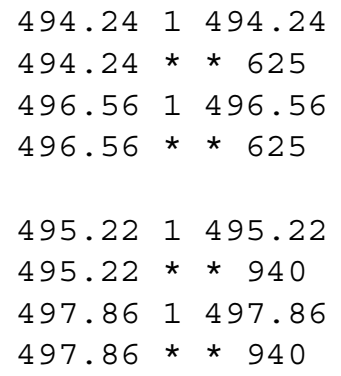




\section{APPENDIX B: \\ WSPRO OUTPUT FILE}


WSPRO OUTPUT FILE

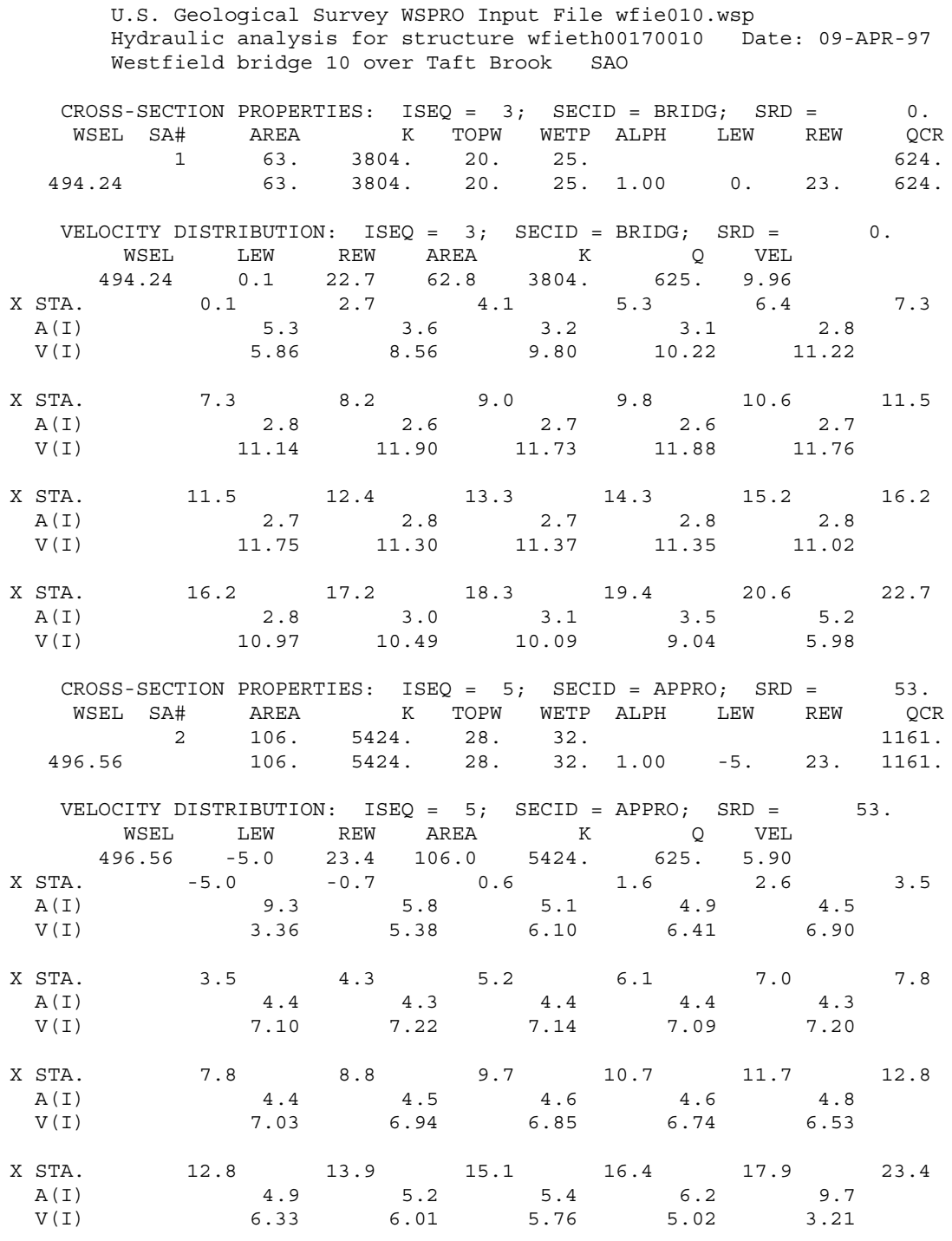


WSPRO OUTPUT FILE (continued)




WSPRO OUTPUT FILE (continued)




WSPRO OUTPUT FILE (continued)

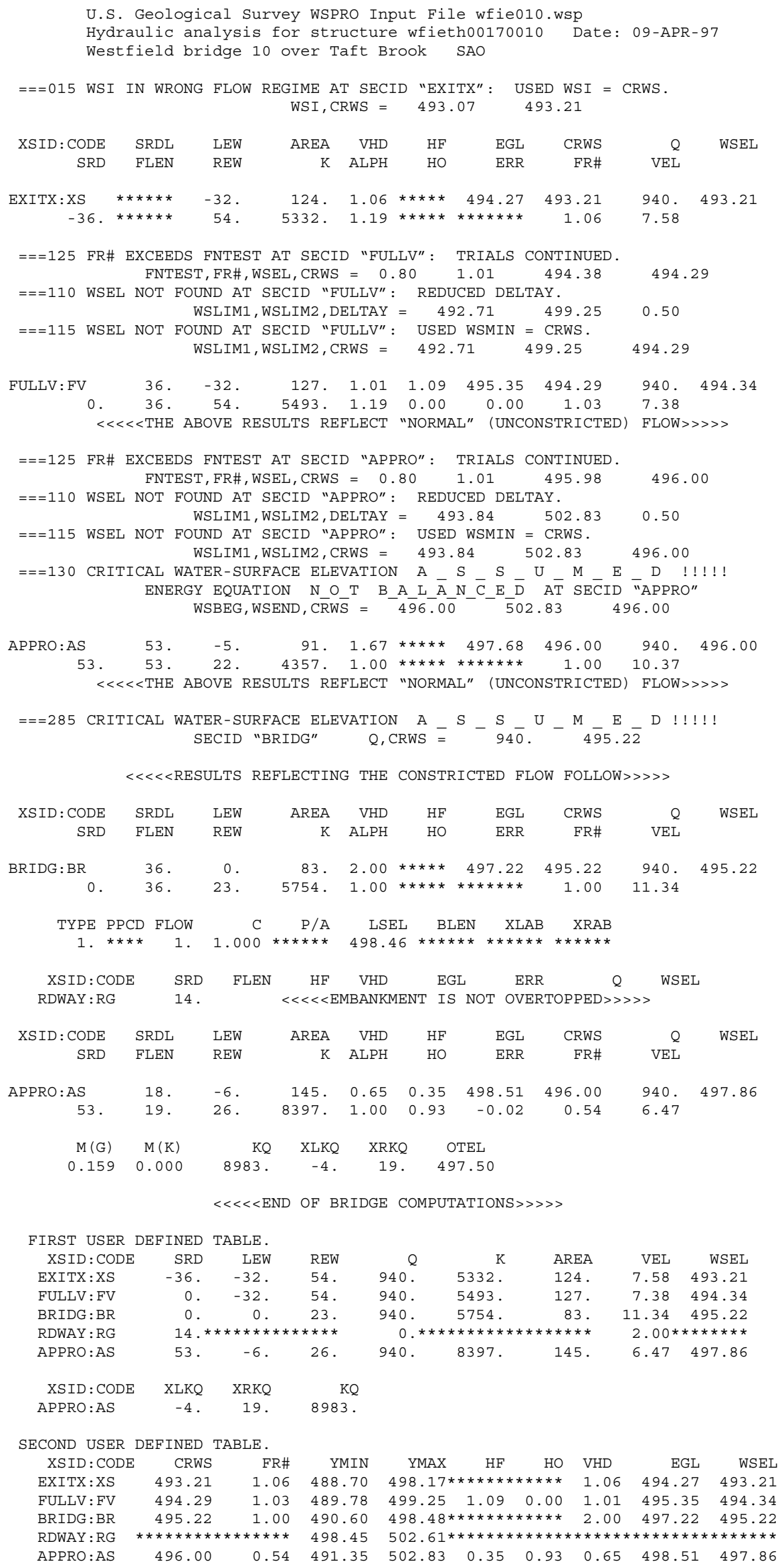




\section{APPENDIX C:}

\section{BED-MATERIAL PARTICAL-SIZE DISTRIBUTION}




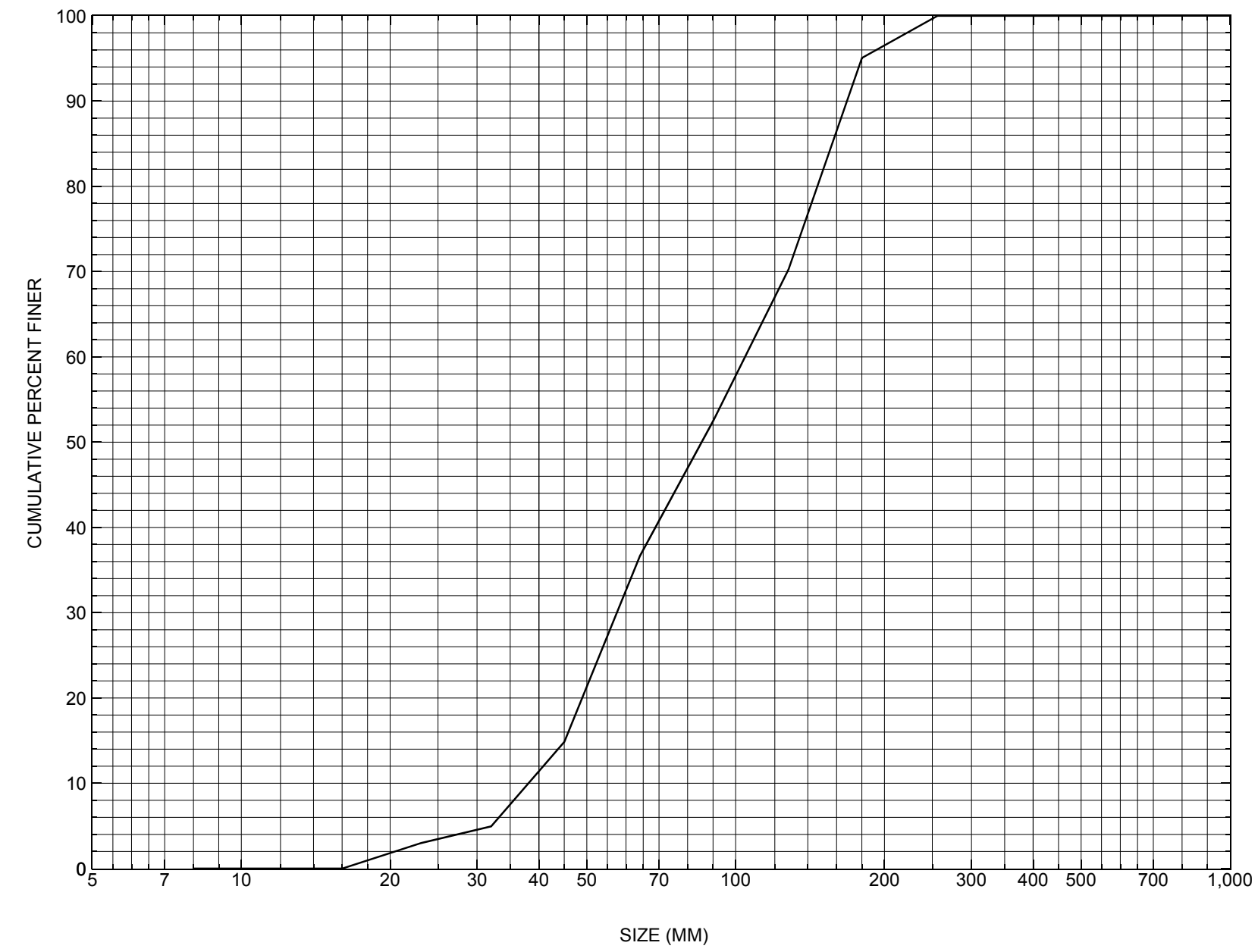

Appendix C. Bed material particle-size distribution for a pebble count in the channel approach of structure WFIETH00170010, in Westfield, Vermont. 


\section{APPENDIX D: \\ HISTORICAL DATA FORM}




\section{Structure Number WFIETH00170010}

\section{General Location Descriptive}

Data collected by (First Initial, Full last name) $\mathbf{E}$. BOEHMLER

Date $(M M / D D / Y Y) \_\mathbf{0 3} / \underline{\mathbf{0 7}} / \underline{\mathbf{9 5}}$

Highway District Number (I - 2; nn) $\mathbf{0 9}$

Town (FIPS place code; I - 4; nnnnn) $\mathbf{8 0 2 0 0}$

Waterway $(I-6)$ TAFT BROOK

Route Number TH017

Topographic Map Lowell

Latitude (I - 16; nnnn.n) $\mathbf{4 4 5 1 8}$
County (FIPS county code; I - 3; nnn)

Mile marker (I - 11; nnn.nnn) $\mathbf{0 0 0 0 0 0}$

Road Name (I - 7): -

Vicinity (I - 9) 0.01 MI TO JCT W C3 TH18

Hydrologic Unit Code: $\underline{\mathbf{0 2 0 1 0 0 0 7}}$

Longitude (i - 17; nnnnn.n) $\mathbf{7 2 2 7 2}$

\section{Select Federal Inventory Codes}

FHWA Structure Number $(I$ - 8) 10101800101018

Maintenance responsibility $(I-21 ; n n) \quad \mathbf{0 3} \quad$ Maximum span length $(I-48 ; n n n n) \underline{\mathbf{0 0 2 4}}$

Year built (I - 27; YYYY) 1968

Structure length (I - 49; nnnnnn) $\underline{\mathbf{0 0 0 0 2 6}}$



Year of ADT (I - 30; YY) $\underline{\mathbf{9 1}}$

Channel \& Protection $(I-61 ; n) \underline{5}$

Opening skew to Roadway $(I-34 ; n n) \quad \mathbf{2 5}$

Waterway adequacy $(I-71 ; n)$

Operational status $(I-41 ; X) \quad \mathbf{A}$

Underwater Inspection Frequency $(I-92 B ; X Y Y) \_\mathbf{N}$

Structure type (I - 43; nnn) $\mathbf{5 0 1}$

Year Reconstructed (I - 106) $\mathbf{0 0 0 0}$

Approach span structure type (I - 44; nnn) $\mathbf{0 0 0}$ Clear span (nnn.n ft) _ _

Number of spans (I - 45; nnn) $\mathbf{0 0 1}$

Vertical clearance from streambed (nnn.n ft) $\underline{\mathbf{7 . 0}}$

Number of approach spans (I - 46; nnnn) $\mathbf{0 0 0 0}$

Waterway of full opening $\left(n n n . n \mathrm{ft}^{2}\right)$

Comments:

The structural inspection report of 7/1/93 indicates the structure is a prestressed voided concrete slab type bridge. Both concrete abutment walls are in like new condition, with the exception of some minor vertical concrete shrinkage cracks. The wingwalls also are in like new condition. The footings are exposed at both abutments. At the upstream end of each abutment the top of the footings are flush with the adjacent streambed. At the downstream end of each abutment the streambed level is about 1.5 feet below the top of the footings. In places, the concrete of the footings has eroded away. Some slight undermining of the downstream left wingwall is noted. The waterway proceeds straight through (Continued, page 31) 


\section{Bridge Hydrologic Data}

Is there hydrologic data available? $\mathbf{N}$ if No, type ctrl- $n$ VTAOT Drainage area $\left(\mathrm{mi}^{2}\right)^{2}$ : -

Terrain character:

Stream character \& type: Mountain stream

Streambed material: Stones and gravel, with some small boulders

Discharge Data (cfs): $\quad \mathrm{Q}_{2.33}-$

$$
\mathrm{Q}_{50}
$$

$\mathrm{Q}_{25}$

$\mathrm{Q}_{500}$

Record flood date (MM /DD/YY): - $/$ - $/$ -

Water surface elevation $(f t):-$

Estimated Discharge (cfs): Velocity at $\mathrm{Q}-$ (ft/s): -

Ice conditions (Heavy, Moderate, Light) : -

Debris (Heavy, Moderate, Light):

The stage increases to maximum highwater elevation (Rapidly, Not rapidly):

The stream response is (Flashy, Not flashy):

Describe any significant site conditions upstream or downstream that may influence the stream's stage: -

Watershed storage area (in percent): - $\%$

The watershed storage area is: - (1-mainly at the headwaters; 2- uniformly distributed; 3-immediatly upstream oi the site)

Water Surface Elevation Estimates for Existing Structure:

\begin{tabular}{|l|l|l|l|l|l|}
\hline Peak discharge frequency & $Q_{2.33}$ & $Q_{10}$ & $Q_{25}$ & $Q_{50}$ & $Q_{100}$ \\
Water surface elevation (ft)) & - & - & - & - & - \\
Velocity $(\mathrm{ft} / \mathrm{sec})$ & - & - & - & - & - \\
\hline
\end{tabular}

Long term stream bed changes: -

Is the roadway overtopped below the $\mathrm{Q}_{100}$ ? (Yes, No, Unknown): $\mathbf{U}$ Frequency: -

Relief Elevation (ft):

Discharge over roadway at $Q_{100}\left(f^{3} / \mathrm{sec}\right)$ :

Are there other structures nearby? (Yes, No, Unknown): Upstream distance (miles): Town: If No or Unknown, type ctrl-n os Highway No. : Structure No. : Year Built:

Clear span (ft): Clear Height (ft): Full Waterway $\left(f^{2}\right)$ : 
Downstream distance (miles): Town: Year Built:

Highway No. : Structure No. : Structure Type:

Clear span (ft): Clear Height $(f t)$ : Full Waterway $\left(f^{2}\right)$ :

Comments:

the structure. The streambed consists of stones and gravel with some small boulders. There are numerous logs and debris across the channel reported near 100 feet upstream. The banks are well stabilized with trees and vegetation. No settlement is noted. Stone fill protection is noted as "little present".

\section{USGS Watershed Data}

Watershed Hydrographic Data

Drainage area $(D A)$

2.39 $\mathrm{mi}^{2}$ Lake and pond area $\mathbf{0}$ $\mathrm{mi}^{2}$

Watershed storage (ST) $\%$

Bridge site elevation 1083 $\mathrm{ft}$ Headwater elevation 2871

Main channel length $\mathbf{3 . 5 3}$ $\mathrm{mi}$ $10 \%$ channel length elevation $\mathbf{1 1 8 1}$ $\mathrm{ft} \quad 85 \%$ channel length elevation 1988 $\mathrm{ft}$

Main channel slope $(S) \quad \mathbf{3 0 4 . 8 5} \mathrm{ft} / \mathrm{mi}$

Watershed Precipitation Data

Average site precipitation in Average headwater precipitation in

Maximum 2yr-24hr precipitation event $(124,2)$ in

Average seasonal snowfall (Sn) $\mathrm{ft}$ 


\section{Bridge Plan Data}

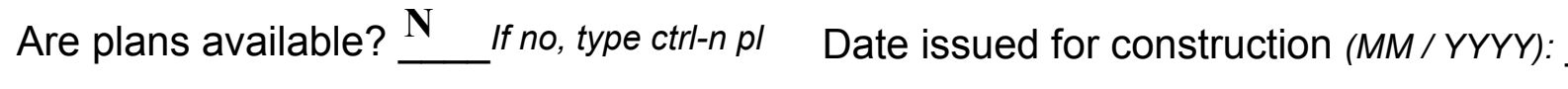

Project Number -

Minimum channel bed elevation:

Low superstructure elevation: USLAB DSLAB USRAB DSRAB Benchmark location description:

Reference Point (MSL, Arbitrary, Other): Datum (NAD27, NAD83, Other):

Foundation Type: 4

If 1: Footing Thickness

If 2: Pile Type: (1-Wood; 2-Stevation:

(1-

(1-Spreadfooting; 2-Pile; 3- Gravity; 4-Unknown)

Footing bottom elevation:

If 3: Footing bottom elevation:
Is boring information available? Foundation Material Type: 3 Briefly describe material at foundation bottom elevation or around piles:

$-$

Comments:

While not expressed explicitly, the footings appear to be spread footing type on mainly regolith material. 


\section{Cross-sectional Data}

Is cross-sectional data available? $\mathbf{N}$ If no, type ctrl-n xs

Source (FEMA, VTAOT, Other)? -

Comments:

\section{NO CROSS SECTION INFORMATION}

\begin{tabular}{|l|l|l|l|l|l|l|l|l|l|l|l|}
\hline Station & - & - & - & - & - & - & - & - & - & - & - \\
\hline Feature & - & - & - & - & - & - & - & - & - & - & - \\
\hline $\begin{array}{l}\text { Low cord } \\
\text { elevation }\end{array}$ & - & - & - & - & - & - & - & - & - & - & - \\
\hline $\begin{array}{l}\text { Bed } \\
\text { elevation }\end{array}$ & - & - & - & - & - & - & - & - & - & - & - \\
\hline $\begin{array}{l}\text { Low cord to } \\
\text { bed length }\end{array}$ & - & - & - & - & - & - & - & - & - & - & - \\
\hline Station & - & - & - & - & - & - & - & - & - & - & - \\
\hline Feature & - & - & - & - & - & - & - & - & - & - & - \\
\hline $\begin{array}{l}\text { Low cord } \\
\text { elevation }\end{array}$ & - & - & - & - & - & - & - & - & - & - & - \\
\hline $\begin{array}{l}\text { Bed } \\
\text { elevation }\end{array}$ & - & - & - & - & - & - & - & - & - & - & - \\
\hline $\begin{array}{l}\text { Low cord to } \\
\text { bed length }\end{array}$ & - & - & - & - & - & - & - & - & - & - & - \\
\hline
\end{tabular}

Source (FEMA, VTAOT, Other)?

Comments: NO CROSS SECTION INFORMATION

\begin{tabular}{|l|l|l|l|l|l|l|l|l|l|l|l|}
\hline Station & - & - & - & - & - & - & - & - & - & - & - \\
\hline Feature & - & - & - & - & - & - & - & - & - & - & - \\
\hline $\begin{array}{l}\text { Low cord } \\
\text { elevation }\end{array}$ & - & - & - & - & - & - & - & - & - & - & - \\
\hline $\begin{array}{l}\text { Bed } \\
\text { elevation }\end{array}$ & - & - & - & - & - & - & - & - & - & - & - \\
\hline $\begin{array}{l}\text { Low cord to } \\
\text { bed length }\end{array}$ & - & - & - & - & - & - & - & - & - & - & - \\
\hline Station & - & - & - & - & - & - & - & - & - & - & - \\
\hline Feature & - & - & - & - & - & - & - & - & - & - & - \\
\hline $\begin{array}{l}\text { Low cord } \\
\text { elevation }\end{array}$ & - & - & - & - & - & - & - & - & - & - & - \\
\hline $\begin{array}{l}\text { Bed } \\
\text { levation }\end{array}$ & - & - & - & - & - & - & - & - & - & - & - \\
\hline $\begin{array}{l}\text { Low cord to } \\
\text { bed length }\end{array}$ & - & - & - & - & - & - & - & - & - & - & - \\
\hline
\end{tabular}




\section{APPENDIX E: \\ LEVEL I DATA FORM}


U. S. Geological Survey

Bridge Field Data Collection and Processing Form

Qa/Qc Check by: $\mathbf{R B}$ Date: $\underline{3 / 26 / 96}$

\section{Structure Number}

WFIETH00170010

Computerized by: $\underline{\mathbf{R B}}$ Date: $4 / 8 / 96$

Reviewd by: SAO Date: $\underline{\mathbf{5} / \mathbf{6} / \mathbf{9 7}}$

\section{A. General Location Descriptive}

1. Data collected by (First Initial, Full last name) D. SONG

2. Highway District Number 09

Date $(M M / D D / Y Y) 06 / \underline{25} / \underline{1995}$

County ORLEANS (019)

Waterway $(I$ - 6) TAFT BROOK

Route Number TH017

3. Descriptive comments:

Located 0.01 miles to the junction with C3 TH18.

Mile marker $\mathbf{0 0 0}$

Town WESTFIELD (80200)

Road Name BALANCE ROCK ROAD

Hydrologic Unit Code: $\mathbf{0 2 0 1 0 0 0 7}$

\section{B. Bridge Deck Observations}
4. Surface cover... LBUS 4
RBUS 4
LBDS 6
RBDS 6
Overall 4

(2b us, ds,lb,rb: 1- Urban; 2- Suburban; 3- Row crops; 4- Pasture; 5- Shrub- and brushland; 6- Forest; 7- Wetland)
5. Ambient water surface... US 2
UB 2
DS 2
(1- pool; 2- riffle)

6. Bridge structure type 1 (1- single span; 2- multiple span; 3- single arch; 4- multiple arch; 5- cylindrical culvert; 6- box culvert; or 7- other)
7. Bridge length $\underline{26}$
(feet)
Span length $\underline{\mathbf{2 4}}$
(feet)
Bridge width 24.3 (feet)

\section{Road approach to bridge:}
8. LB 0
RB 1
( 0 even, 1- lower, 2- higher)
9. LB_2
RB $\underline{2}$
(1-Paved, 2- Not paved)

10. Embankment slope (run / rise in feet / foot)

US left

US right

\begin{tabular}{|c|c|c|c|}
\hline \multicolumn{2}{|c|}{ Protection } & \multirow{2}{*}{ 13.Erosion } & 14.Severity \\
\hline 11.Type & 12.Cond. & $\mathbf{2}$ & $\mathbf{1}$ \\
\hline $\mathbf{2}$ & $\mathbf{2}$ & $\underline{\mathbf{2}}$ & $\mathbf{-}$ \\
\hline $\mathbf{1}$ & $\mathbf{1}$ & $\mathbf{0}$ & $\mathbf{1}$ \\
\hline $\mathbf{2}$ & $\mathbf{1}$ & $\mathbf{1}$ & $\mathbf{0}$ \\
\hline $\mathbf{2}$ & $\mathbf{2}$ & $\mathbf{2}$ & $\mathbf{1}$ \\
\hline
\end{tabular}

Bank protection types: 0- none; 1- < 12 inches,

2- $<36$ inches; $3-<48$ inches;

4- < 60 inches; 5- wall / artificial levee

Bank protection conditions: 1- good; 2- slumped;

3- eroded; 4- failed

Erosion: 0 - none; 1- channel erosion; 2 -

road wash; 3- both; 4- other

Erosion Severity: 0 - none; 1- slight; 2- moderate; 3- severe

\section{Channel approach to bridge (BF):}

15. Angle of approach: $\mathbf{0}$

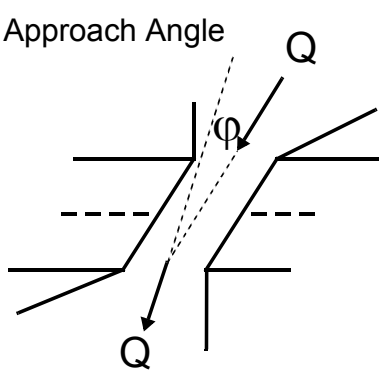

17. Channel impact zone 1 :

Where? LB $(L B, R B)$

Range? 10 feet US

Channel impact zone 2:

Where? _ _ $(L B, R B)$

Range? - $\quad$ feet -

(US, UB, DS) to = feet Impact Severity: 0- none to very slight; 1- Slight; 2- Moderate; 3- Severe

16. Bridge skew: 15 Bridge Skew Angle



\section{Exist? $\mathbf{Y}(Y$ or $N)$}

Severity 2

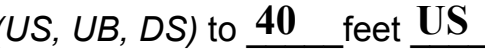

Exist? $\mathbf{N}(Y$ or $N)$

Severity - 
18. Bridge Type: 1a

1a- Vertical abutments with wingwalls

1 b- Vertical abutments without wingwalls

2- Vertical abutments and wingwalls, sloping embankment

Wingwalls perpendicular to abut. face

3- Spill through abutments

4- Sloping embankment, vertical wingwalls and abutments

Wingwall angle less than $90^{\circ}$.

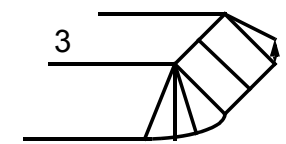

19. Bridge Deck Comments (surface cover variations, measured bridge and span lengths, bridge type variations, approach overflow width, etc.)

4. On the right bank DS there are shrubs and pasture close to the bridge and forest beyond. On the left bank DS there is forest one bridge length away from the stream and a road and pasture beyond.

7. Values are from the VT AOT files.

18. The wingwalls are a combination of $1 \mathrm{a}$ and 4 but there is no embankment.

\section{Upstream Channel Assessment}

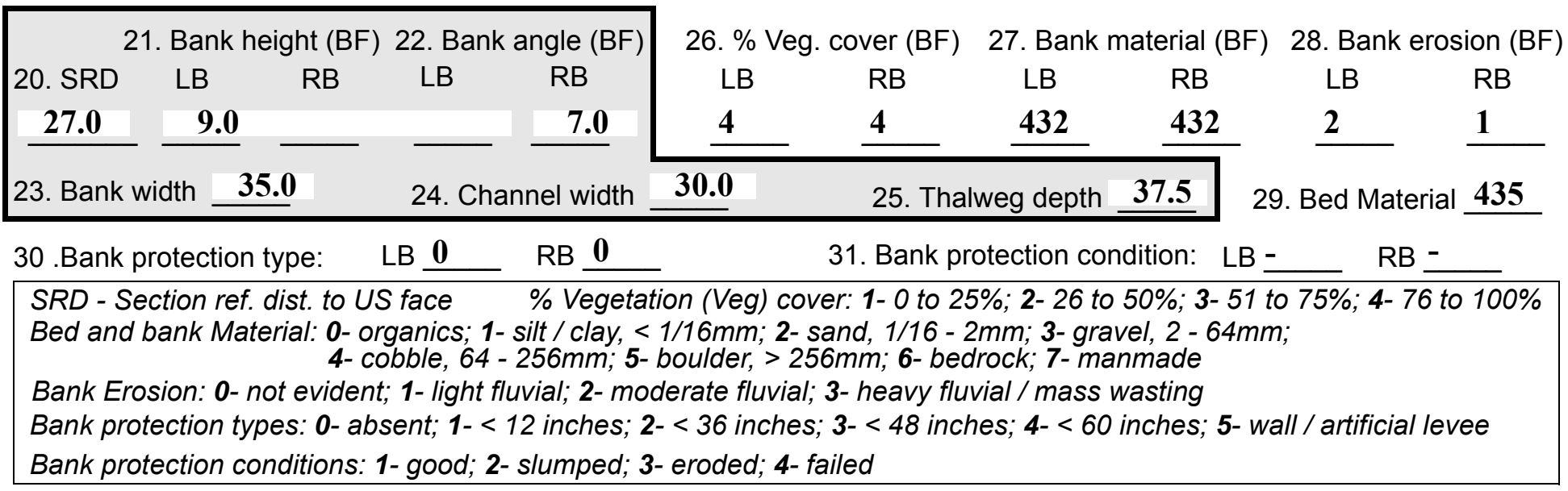

32. Comments (bank material variation, minor inflows, protection extent, etc.):

There is a large debris accumulation across the channel at 80 feet US with the potential to clog the bridge opening. 
36. Point bar extent: 4 feet $\underline{\mathbf{U S}}$ (US, UB) to $\mathbf{8 0}$ feet $\underline{\mathbf{U S}}$

(US, UB, DS) positioned $\underline{\mathbf{0}}$ \%LB to $\underline{\mathbf{5 0}} \%$ RB

37. Material: 4

38. Point or side bar comments (Circle Point or Side; Note additional bars, material variation, status, etc.):

The side bar is established behind the major debris pile 80 feet US which pushes flow to the right bank.

39. Is a cut-bank present? $\mathbf{Y}$ (Y or if $N$ type ctrl-n cb)

40. Where? $\underline{\text { LB }}$ (LB or RB)

41. Mid-bank distance: $\mathbf{5 0}$

42. Cut bank extent: 15 feet US (US, UB, DS)

43. Bank damage: 2

(1- eroded and/or creep; 2- slip failure; 3- block failure)

44. Cut bank comments (eg. additional cut banks, protection condition, etc.):

Tree roots are exposed and undermined and the bank material is slumping.

45. Is channel scour present? $\mathbf{N}$ ( $Y$ or if $N$ type ctrl-n cs)

47. Scour dimensions: Length -

Width -

Depth : -

46. Mid-scour distance: -

48. Scour comments (eg. additional scour areas, local scouring process, etc.):

NO CHANNEL SCOUR

49. Are there major confluences? $\mathbf{N}$

51. Confluence 1: Distance -

Confluence 2: Distance -

54. Confluence comments (eg. confluence name):

NO MAJOR CONFLUENCES
( $Y$ or if $N$ type ctrl-n $m c)$

52. Enters on -

Enters on ( $L B$ or $R B)$ (LB or $R B)$
50. How many? -

53. Type(1- perennial; 2- ephemeral)

Type (1-perennial; 2- ephemeral)

\section{Under Bridge Channel Assessment}

55. Channel restraint (BF)? LB 2

56. Height (BF) 57 Angle (BF)

LB RB

18.5

58. Bank width (BF) 1.0 (1- natural bank; 2- abutment; 3- artificial levee)

59. Channel width (Amb)
61. Material (BF)
LB RB
$\underline{2} \quad \underline{ }$
62. Erosion (BF)
LB RB
7
60. Thalweg depth (Amb) $\mathbf{9 0 . 0}$

63. Bed Material -

Bed and bank Material: 0- organics; 1- silt / clay, < 1/16mm; 2- sand, 1/16 - 2mm; 3- gravel, 2 - 64mm; 4- cobble, 64 - 256mm; 5- boulder, > 256mm; 6- bedrock; 7- manmade

Bank Erosion: 0- not evident; 1- light fluvial; 2- moderate fluvial; 3- heavy fluvial / mass wasting

64. Comments (bank material variation, minor inflows, protection extent, etc.):

435 
65. Debris and Ice Is there debris accumulation?

(Yor $N)$ 66. Where? $\underline{Y}$

(1- Upstream; 2- At bridge; 3- Both)

67. Debris Potential 1 (1-Low; 2-Moderate; 3- High)

68. Capture Efficiency 2

(1-Low; 2- Moderate; 3- High)

69. Is there evidence of ice build-up? 2

Ice Blockage Potential $\mathbf{N}$

(1- Low; 2- Moderate; 3- High)

70. Debris and Ice Comments:

1

There is a large debris pile of logs and twigs 80 feet US that is already constricting flow. The bridge has a low vertical clearance from the streambed and has good potential to trap debris.

\begin{tabular}{|l|c|c|c|c|c|c|c|c|}
\hline Abutments & $\begin{array}{c}71 . \text { Attack } \\
\angle \text { (BF) }\end{array}$ & $\begin{array}{c}72 \text {. Slope } \angle \\
\text { (Qmax) }\end{array}$ & $\begin{array}{c}\text { 73. Toe } \\
\text { loc. (BF) }\end{array}$ & $\begin{array}{c}\text { 74. Scour } \\
\text { Condition }\end{array}$ & $\begin{array}{c}75 . \text { Scour } \\
\text { depth }\end{array}$ & $\begin{array}{c}\text { 76. Exposure } \\
\text { depth }\end{array}$ & 77. Material & 78. Length \\
\hline LABUT & & $\mathbf{5}$ & $\mathbf{9 0}$ & $\mathbf{2}$ & $\mathbf{3}$ & $\mathbf{0}$ & $\mathbf{1 . 5}$ & $\mathbf{9 0 . 0}$ \\
\hline RABUT & $\mathbf{1}$ & - & $\mathbf{9 0}$ & & & $\mathbf{2}$ & $\mathbf{3}$ & $\mathbf{2 1 . 0}$ \\
\hline
\end{tabular}

Pushed: $L B$ or RB

Toe Location (Loc.): 0- even, 1- set back, 2- protrudes

Scour cond.: 0- not evident; 1- evident (comment); 2- footing exposed; 3-undermined footing; 4- piling exposed; 5- settled; 6- failed

Materials: 1- Concrete; 2- Stone masonry or drywall; 3- steel or metal; 4- wood

79. Abutment comments (eg. undermined penetration, unusual scour processes, debris, etc.):

0

1.5

1

There is slight undermining and erosion of both abutments. Both the left and the right abutment footings are exposed 1.4 feet and undermined 0.1 foot.

80. Wingwalls:

Exist? Material? Scour Scour Exposure $\begin{aligned} & 81 . \\ & \text { Angle? Length? }\end{aligned}$ Condition? depth? depth?

USLWW:

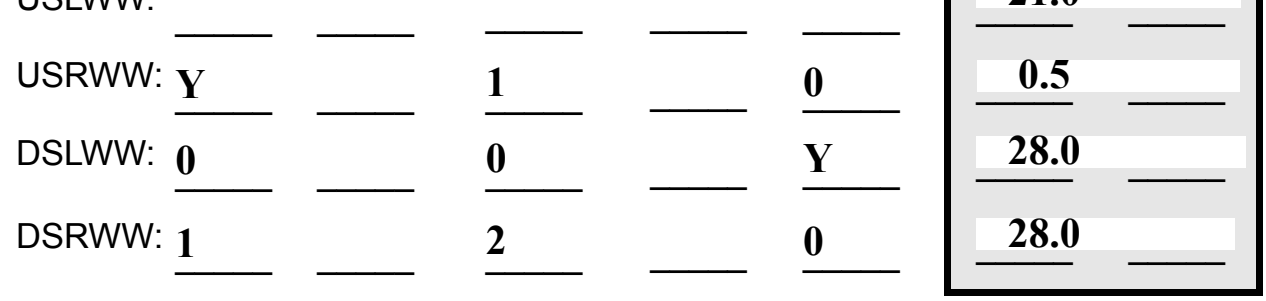

Wingwall materials: 1- Concrete; 2- Stone masonry or drywall; 3- steel or metal; 4- wood

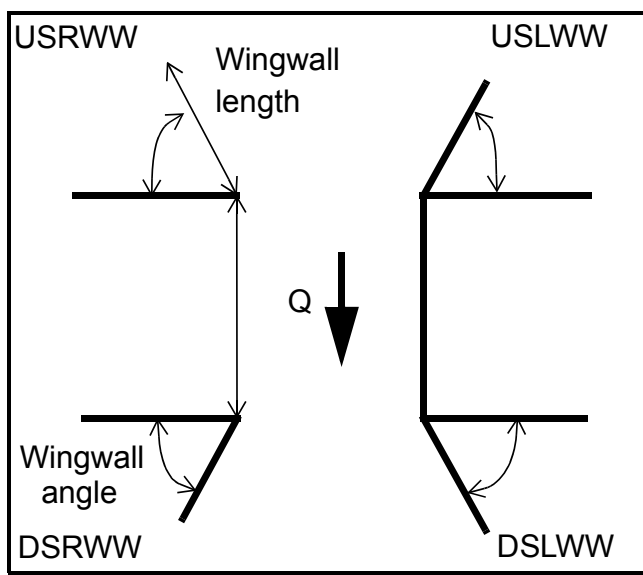

82. Bank / Bridge Protection:

\begin{tabular}{|l|l|l|l|l|l|l|c|c|}
\hline Location & USLWW & USRWW & LABUT & RABUT & LB & RB & DSLWW & DSRWW \\
\hline Type & $\mathbf{0 . 8}$ & $\mathbf{3}$ & $\mathbf{Y}$ & $\mathbf{0}$ & $\mathbf{1}$ & $\mathbf{1}$ & - & - \\
\hline Condition & $\mathbf{Y}$ & $\mathbf{0}$ & $\mathbf{1}$ & $\mathbf{2 . 3}$ & $\mathbf{2}$ & $\mathbf{2}$ & - & - \\
\hline Extent & $\mathbf{1}$ & $\mathbf{1 . 2}$ & $\mathbf{3}$ & $\mathbf{2}$ & $\mathbf{2}$ & $\mathbf{0}$ & $\mathbf{0}$ & - \\
\hline
\end{tabular}

Bank / Bridge protection types: 0- absent; 1-<12 inches; 2- < 36 inches; 3- < 48 inches; 4- < 60 inches; 
83. Wingwall and protection comments (eg. undermined penetration, unusual scour processes, etc.):

-
-
-
-
-
2
1
3
2
1
3

\section{Piers:}

84. Are there piers? Th (Y or if N type ctrl-n pr)

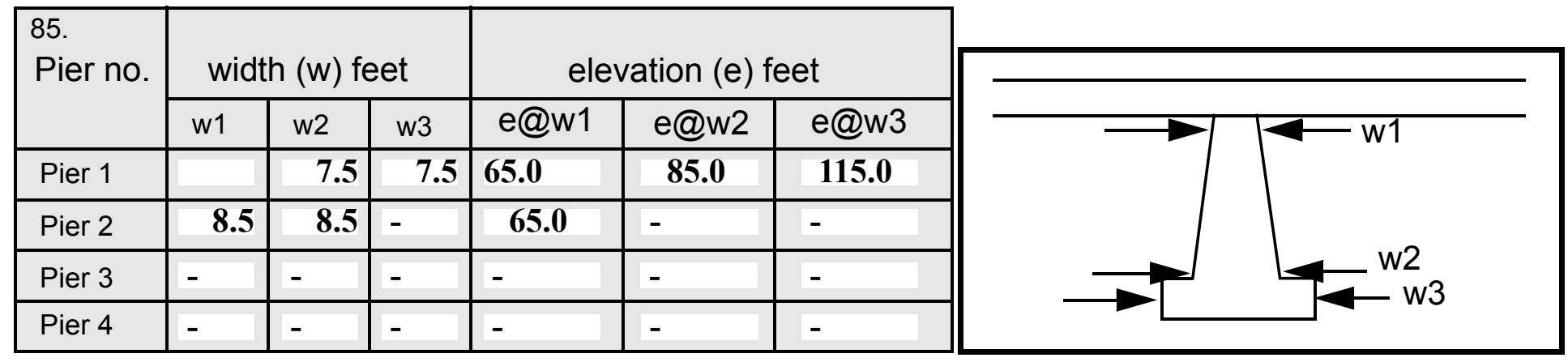

\begin{tabular}{|l|l|l|l|l|}
\hline Level 1 Pier Descr. & \multicolumn{1}{|c|}{1} & \multicolumn{1}{|c|}{2} & \multicolumn{1}{|c|}{3} & 4 \\
\hline 86. Location (BF) & e DS & foot of & sed 1.5 & \\
\hline 87. Type & left & unde & feet & \\
\hline 88. Material & wing & rmin & with & \\
\hline 89. Shape & wall & ing. & $\mathbf{0 . 8}$ & \\
\hline 90. Inclined? & foot- & The & foot & \\
\hline 91. Attack $\angle$ (BF) & ingis & DS & unde & \\
\hline 92. Pushed & expo & right & rmin & \\
\hline 93. Length (feet) & - & - & - & - \\
\hline 94. \# of piles & sed & wing & ing & \\
\hline 95. Cross-members & $\mathbf{1 . 1}$ & wall & at its & N \\
\hline 96. Scour Condition & feet & foot- & US & - \\
\hline 97. Scour depth & with & ing is & end. & - \\
\hline 98. Exposure depth & $\mathbf{0 . 1}$ & expo & & - \\
\hline
\end{tabular}

LFP, LTB, LB, MCL, MCM, MCR, RB, RTB, RFP

1- Solid pier, 2- column, 3- bent

1-Wood; 2- concrete; 3- metal; 4- stone

1- Round; 2- Square; 3- Pointed

Y-yes; $N$ - no

$L B$ or $R B$

0- none; 1- laterals; 2- diagonals; 3- both

0- not evident; 1- evident (comment);

2- footing exposed; 3- piling exposed;

4- undermined footing; 5- settled; 6- failed 
99. Pier comments (eg. undermined penetration, protection and protection extent, unusual scour processes, etc.):

-
-
-
-
-
-
-
-
-

100.

\section{E. Downstream Channel Assessment}

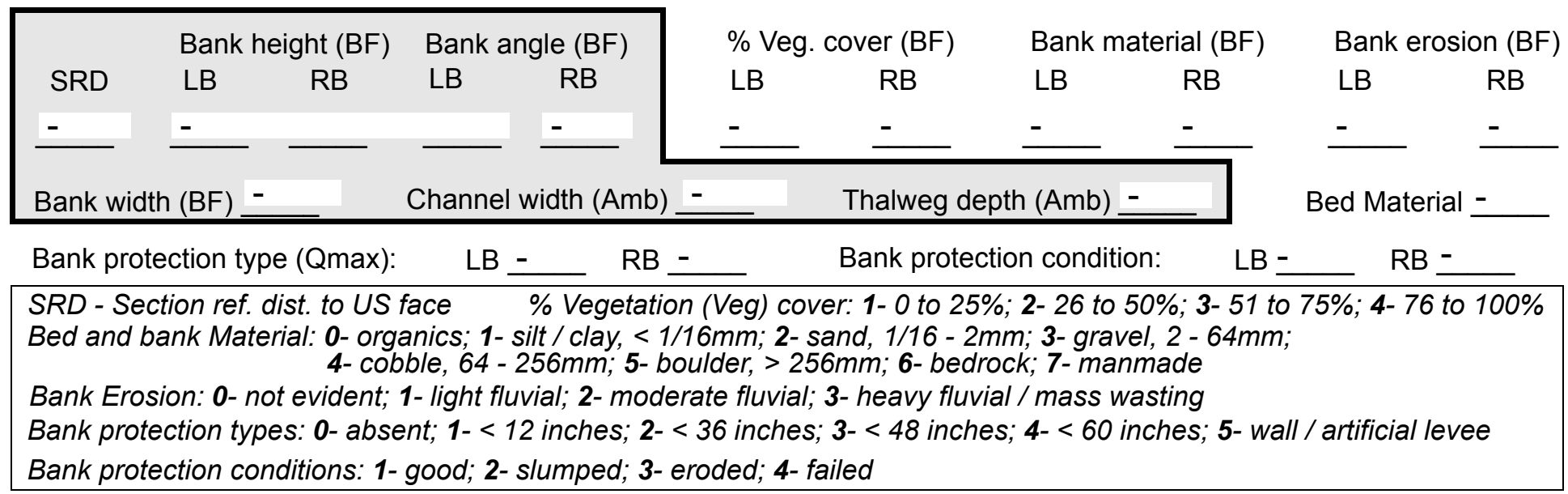

Comments (eg. bank material variation, minor inflows, protection extent, etc.):

$-$

$-$

-

$-$

$-$

$-$

$-$

$-$

$-$

$-$

$-$

$-$

$-$

$-$

$-$

101. Is a drop structure present? _ ( $Y$ or $N$, if $N$ type ctrl-n ds) 102. Distance: ___ feet 103. Drop: __ feet 104. Structure material: ___ (1- steel sheet pile; 2- wood pile; 3- concrete; 4- other) 105. Drop structure comments (eg. downstream scour depth):

$-$

$-$

$-$

$-$

$-$

$-$ 
106. Point/Side bar present? (Y or N. if $N$ type ctrl-n pb)Mid-bar distance: NO Mid-bar width: PIE

Point bar extent: $\mathbf{R S}$ feet (US, UB, DS) to feet (US, UB, DS) positioned $\%$ LB to $\% R B$

Material:

Point or side bar comments (Circle Point or Side; note additional bars, material variation, status, etc.):

4

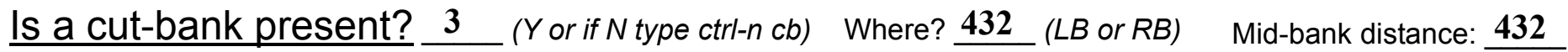
Cut bank extent: $\underline{\mathbf{0}}$ feet $\underline{\mathbf{0}}$ (US, UB, DS) to $\underline{435}$ feet $\underline{\mathbf{0}}$ (US, UB, DS)

Bank damage: $\mathbf{0}$ (1- eroded and/or creep; 2- slip failure; 3- block failure)

Cut bank comments (eg. additional cut banks, protection condition, etc.):

$-$

Bank erosion is not evident within 2 bridge lengths, but steep cutting of both banks exist further DS.

Is channel scour present? ( $Y$ or if $N$ type ctrl-n cs)

Mid-scour distance:

Scour dimensions: Length Depth:

Positioned

$\%$ LB to $\% \mathrm{RB}$

Scour comments (eg. additional scour areas, local scouring process, etc.):

Are there major confluences?

Confluence 1: Distance $\mathbf{N}$

Confluence 2: Distance $\underline{\text { DRO }}$

Confluence comments (eg. confluence name):

UCTURE (Y or if $N$ type ctrl-n mc)

Enters on (LB or $R B)$

Enters on $\underline{\mathbf{P}}$ (LB or $R B)$
How many?

Type NO (1- perennial; 2- ephemeral)

Type $\underline{\text { STR (1- perennial; 2- ephemeral) }}$

\section{F. Geomorphic Channel Assessment}

107. Stage of reach evolution
1- Constructed

2- Stable

3- Aggraded

4- Degraded

5- Laterally unstable

6- Vertically and laterally unstable 
108. Evolution comments (Channel evolution not considering bridge effects; See HEC-20, Figure 1 for geomorphic descriptors):

$\mathbf{N}$

$-$

$-$

$-$

$-$

$-$

$-$

-

$-$ 


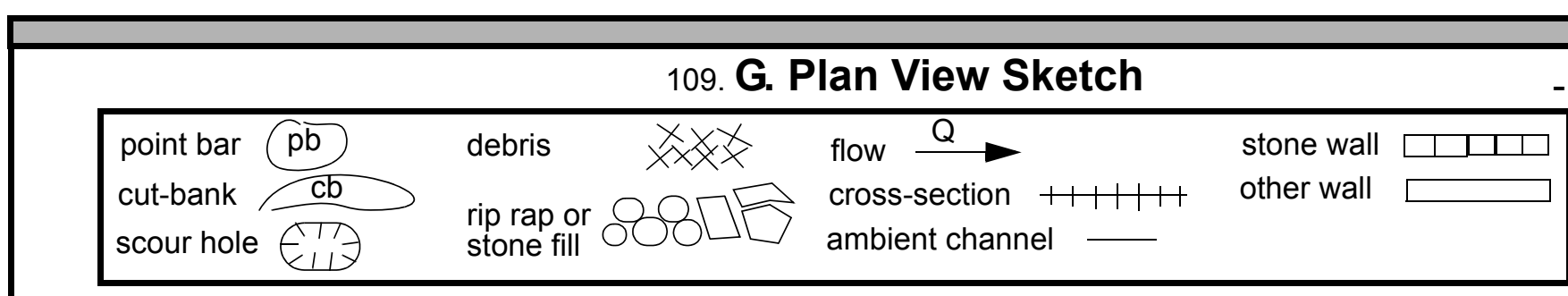


APPENDIX F:

SCOUR COMPUTATIONS 





Clear water Contraction Scour in MAIN CHANNEL

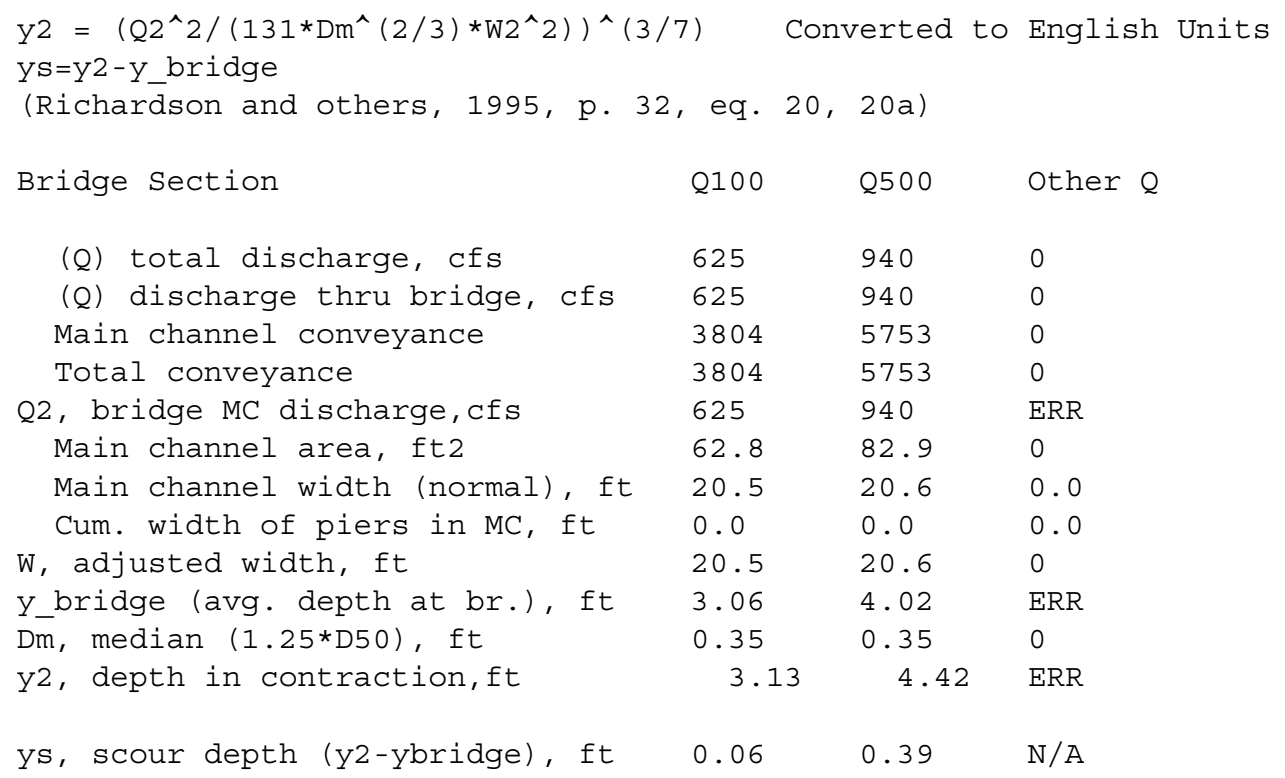

\begin{tabular}{|c|c|c|c|}
\hline \multicolumn{4}{|l|}{ rmoring } \\
\hline \multicolumn{4}{|c|}{$\begin{array}{l}\mathrm{DC}=\left[\left(1.94 * \mathrm{~V}^{\wedge} 2\right) /(5.75 * \log (12.27 * \mathrm{Y} / \mathrm{D} 90))^{\wedge} 2\right] /[0.03 *(165-62.4)] \\
\text { Depth to Armoring }=3 *(1 / \mathrm{PC}-1)\end{array}$} \\
\hline $\begin{array}{l}\text { Depth to Armoring }=3 *(1 / \mathrm{Pc}-1) \\
\text { (Federal Highway Administration, } 19\end{array}$ & & & \\
\hline Downstream bridge face property & $100-y r$ & $500-y r$ & Other $Q$ \\
\hline Q, discharge thru bridge $\mathrm{MC}$, cfs & 625 & 940 & $\mathrm{~N} / \mathrm{A}$ \\
\hline Main channel area (DS), ft2 & 62.8 & 82.9 & 0 \\
\hline Main channel width (normal), ft & 20.5 & 20.6 & 0.0 \\
\hline Cum. width of piers, ft & 0.0 & 0.0 & 0.0 \\
\hline Adj. main channel width, ft & 20.5 & 20.6 & 0.0 \\
\hline D90, ft & 0.5509 & 0.5509 & 0.0000 \\
\hline D95, ft & 0.5901 & 0.5901 & 0.0000 \\
\hline tical grain size, ft & 0.5614 & 0.6430 & $\mathrm{ERR}$ \\
\hline PC, Decimal percent coarser than Dc & 0.086 & 0.038 & 0.000 \\
\hline
\end{tabular}


Froehlich's Abutment Scour

$\mathrm{Ys} / \mathrm{Y} 1=2.27 * \mathrm{~K} 1 * \mathrm{~K} 2 *\left(\mathrm{a}^{\prime} / \mathrm{Y} 1\right) \wedge 0.43 * \mathrm{Fr} 1 \wedge 0.61+1$

(Richardson and others, 1995, p. 48, eq. 28)

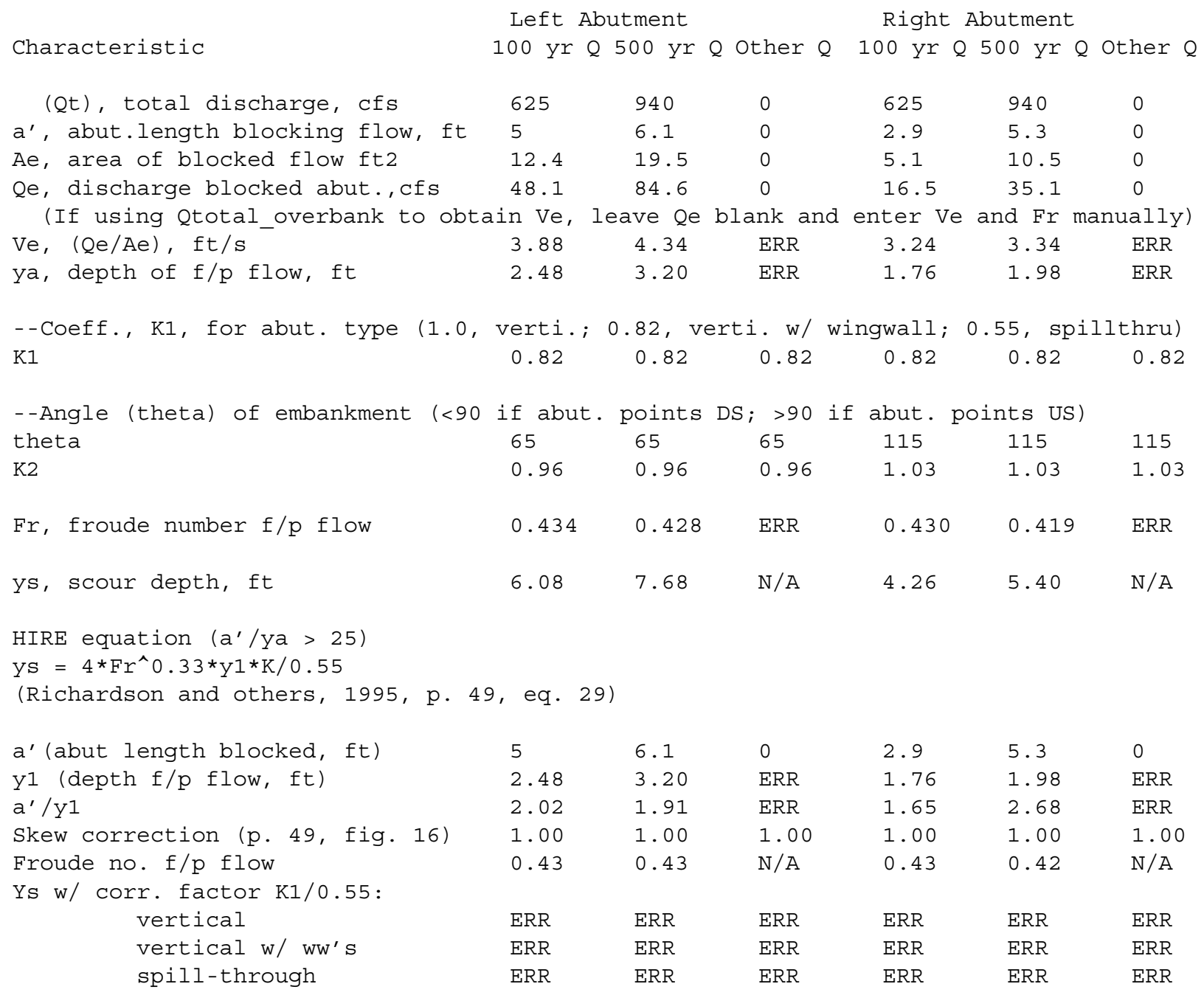






